University of Nebraska - Lincoln

DigitalCommons@University of Nebraska - Lincoln

2010

Remote sensing of phytoplankton pigment distribution in the United States northeast coast

\author{
Xiaoju Pan \\ NASA Goddard Space Flight Center, xpanx001@gmail.com \\ Antonio Mannino \\ NASA Goddard Space Flight Center \\ Mary E. Russ \\ NASA Goddard Space Flight Center \\ Stanford B. Hooker \\ NASA Goddard Space Flight Center \\ Lawrence Harding \\ University of Maryland Center for Environmental Science
}

Follow this and additional works at: https://digitalcommons.unl.edu/nasapub

Part of the Physical Sciences and Mathematics Commons

Pan, Xiaoju; Mannino, Antonio; Russ, Mary E.; Hooker, Stanford B.; and Harding, Lawrence, "Remote sensing of phytoplankton pigment distribution in the United States northeast coast" (2010). NASA Publications. 78.

https://digitalcommons.unl.edu/nasapub/78

This Article is brought to you for free and open access by the National Aeronautics and Space Administration at DigitalCommons@University of Nebraska - Lincoln. It has been accepted for inclusion in NASA Publications by an authorized administrator of DigitalCommons@University of Nebraska - Lincoln. 


\title{
Remote sensing of phytoplankton pigment distribution in the United States northeast coast
}

\author{
Xiaoju Pan ${ }^{\text {a,* }}$, Antonio Mannino ${ }^{\text {a }}$, Mary E. Russ ${ }^{\text {a }}$, Stanford B. Hooker ${ }^{\text {a }}$, Lawrence W. Harding Jr. ${ }^{\text {b }}$ \\ ${ }^{a}$ NASA Goddard Space Flight Center, Greenbelt, MD 20771, USA \\ ${ }^{\mathrm{b}}$ Horn Point Laboratory, University of Maryland Center for Environmental Science, Box 775, Cambridge, MD 21613, USA
}

\section{A R T I C L E I N F O}

Article history:

Received 12 September 2009

Received in revised form 30 March 2010

Accepted 11 May 2010

\section{Keywords:}

Phytoplankton pigments

Remote sensing

U.S. northeast coast

SeaWiFS

MODIS-Aqua

\begin{abstract}
A B S T R A C T
Phytoplankton pigments constitute many more compounds than chlorophyll $a$ that can be applied to study phytoplankton diversity, populations, and primary production. In this study, field measurements were applied to develop ocean color satellite algorithms of phytoplankton pigments from in-water radiometry measurements. The match-up comparisons showed that the satellite-derived pigments from our algorithms agree reasonably well (e.g. $30-55 \%$ of uncertainty for SeaWiFS and $37-50 \%$ for MODIS-Aqua) to field data, with better agreement (e.g. 30-38\% of uncertainty for SeaWiFS and 39-44\% for MODIS-Aqua) for pigments abundant in diatoms. The seasonal and spatial variations of satellite-derived phytoplankton biomarker pigments, such as fucoxanthin, which is abundant in diatoms, peridinin, which is found only in peridinincontaining dinoflagellates, and zeaxanthin, which is primarily from cyanobacteria in coastal waters, revealed that higher densities of diatoms are more likely to occur on the inner shelf and during winter-spring and obscure other abundant phytoplankton groups. However, relatively higher densities of other phytoplankton, such as dinoflagellates and cyanobacteria, are likely to occur on the mid- to outer-continental shelf and during summer. Seasonal variation of riverine discharge may play an important role in stimulating algal blooms, in particular diatoms, while higher abundances of cyanobacteria coincide with warmer water temperatures and lower nutrient concentrations.
\end{abstract}

(c) 2010 Elsevier Inc. All rights reserved.

\section{Introduction}

One of the primary objectives of satellite ocean color remote sensing is to retrieve the distribution of phytoplankton pigment concentrations, and therefore phytoplankton biomass and primary production (PP) (IOCCG, 1999, 2000; McClain, 2009). The present PP models are typically based on the estimation of chlorophyll $a$ concentration ([Chl_a]), along with physical parameters such as sea-surface temperature (SST) and photosynthetically available radiation (PAR) (Behrenfeld \& Falkowski, 1997; Behrenfeld et al., 2005; Marra et al., 2003, 2007). Such PP models assume that phytoplankton capability to capture light can be represented by [Chl_a] without considering the variability of the phytoplankton composition. Other chlorophyll (e.g. chlorophyll $b$ and $c$ ) and photosynthetic carotenoid pigments (PSC; e.g. fucoxanthin and peridinin), however, can also capture light, and their relative concentrations to [Chl_a] vary among phytoplankton species (Jeffrey et al., 1997; Mackey et al., 1996). Chlorophyll $b$ (Chl_b) and peridinin (Perid), for

\footnotetext{
* Corresponding author. Current address: Research Center for Environmental Changes, Academia Sinica, 128 Academia Road, Section 2, Nankang, Taipei 115, Taiwan. Tel.: +88622653 9885x870.

E-mail address: xpanx001@gmail.com (X. Pan).
}

example, do not exist in diatoms but in green algae (e.g. prasinophytes and chlorophytes) and dinoflagellates, respectively (Jeffrey et al., 1997; Mackey et al., 1996). The presence of photoprotective carotenoid pigments (PPC; e.g. diadinoxanthin, diatoxanthin, and zeaxanthin) may further decrease the proportion of PAR utilized for primary production (Marra et al., 2000; Sathyendranath et al., 1996; Sosik \& Mitchell, 1995). Detailed knowledge of phytoplankton pigment composition, thus, may improve current PP models (Uitz et al., 2009). Information on phytoplankton pigment composition may also improve our understanding of algal biodiversity and taxonomic composition through appropriate chemotaxonomic analysis (e.g. CHEMTAX; Mackey et al., 1996), which in turn improves our understanding of the impacts of climate change and pollution on ocean ecosystems. In addition, some pigments are relatively unique biomarkers for certain phytoplankton in coastal waters, e.g. alloxanthin in cryptophytes, peridinin in peridinincontaining dinoflagellates, and zeaxanthin primarily from cyanobacteria in coastal waters (Jeffrey et al., 1997; Mackey et al., 1996). The study of phytoplankton pigment distributions can provide a useful analytical tool to monitor algal blooms if the seasonal and regional relationships between taxa-specific pigments and cell counts can be well understood. For example, the notorious dinoflagellate bloom of Alexandrium fundyense, which is thought to have caused a serious paralytic shellish poisoning (PSP) threat in southern New England in the United States (U.S.) (Anderson et al., 2005), may be detected through peridinin 
concentration retrieved from satellites if the cellular peridinin concentration is known.

Satellite remote sensing constitutes a valuable tool to study biogeochemical processes, especially within dynamic coastal waters, as compared with traditional ship surveys (IOCCG, 1999, 2000; McClain, 2009). Although satellite sensors do not measure pigments directly, empirical or semi-analytical models can be applied to derive them from satellite observations of ocean water-leaving radiances (Carder et al., 1991; Garver \& Siegel, 1997; Lee \& Carder, 2004; Maritorena et al., 2002; O'Reilly et al., 1998, 2000; Sathyendranath et al., 1994; Smyth et al., 2002). Present pigment algorithms focus almost exclusively on Chl_a (e.g. OC4V4 and OC3M algorithms) (O'Reilly et al., 1998, 2000). Such algorithms were derived from data collected primarily in oceanic waters, and validation studies for optically complex inner shelf waters (Case 2) are sparse (e.g. Magnuson et al., 2004; Pan et al., 2008).

Empirical algorithms were developed in this paper from nearly coincident collection of field remote sensing reflectance $\left(R_{\mathrm{rs}}\right)$ data and samples for phytoplankton pigment distributions along the U.S. northeast coast (Fig. 1). This region covers a wide range of water types, including the Gulf Stream, the optically complex Middle Atlantic Bight (MAB), which is significantly influenced by freshwater outflow from the Chesapeake and Delaware Bays and Hudson-Raritan Rivers, and the Gulf of Maine (GoM), which is influenced by direct riverine inputs as well as the Scotian shelf/slope water (O'Reilly \& Zetlin, 1998). The bio-optical properties in this region represent both typical Case 1 and Case 2 waters. The seasonal variation of phytoplankton species composition is apparent for this study region. Diatom blooms are common during winter-spring and possibly during fall, while blooms of dinoflagellates, chrysophytes, and cyanobacteria can occur during summer off New England, within the New York Bight, and the southern MAB sub-regions, respectively (ECOHAB, 1994). The relative pigment composition consequently varies seasonally and spatially in this region, which presents a challenge for studying phytoplankton pigment distributions from space. The objectives of this study are (1) to develop algorithms for the distributions of individual phytoplankton pigments in the U. S. northeast coast and validate the algorithms with satellite data within a reasonable uncertainty (e.g. $\pm 35 \%$ of errors); and (2) to evaluate the seasonal and spatial variability of phytoplankton pigment distributions and the possible factors that produce these distributions.

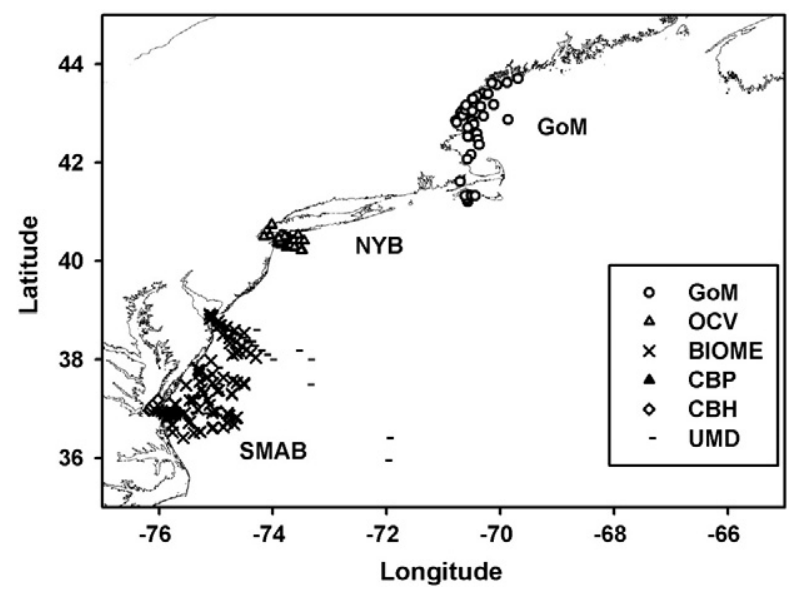

Fig. 1. Map of the study area within the United States (U.S.) northeast coastal region. Field sampling was conducted in the Gulf of Maine (GoM), New York Bight (NYB) for a series of Ocean Color Validation cruises (OCV), the Southern Middle Atlantic Bight (SMAB) for a series of Bio-physical Interactions in Ocean Margin Ecosystems cruises (BIOME), Chesapeake Bay Plume cruises (CBP), and Chesapeake Bay mouth Hydrological survey ( $\mathrm{CBH}$ ). Locations for data collected by L. Harding, Jr. and colleagues from the University of Maryland (UMD) are also shown.

\section{Materials and methods}

\subsection{Field experiments}

This study focused on the U.S. northeast coast with longitude and latitude limited to $-77^{\circ} \mathrm{W}$ to $-65^{\circ} \mathrm{W}$ and $35^{\circ} \mathrm{N}$ to $45^{\circ} \mathrm{N}$, respectively (Fig. 1). Sub-areas including the Gulf of Maine (GoM; latitude $>41.65^{\circ} \mathrm{N}$ ), the New York Bight (NYB; latitude between $39.5^{\circ}$ $\mathrm{N}$ and $41.65^{\circ} \mathrm{N}$ ), and the southern Middle Atlantic Bight (SMAB; latitude $<39.5^{\circ} \mathrm{N}$ ) were demarcated for descriptive convenience (Fig. 1). Multiple cruises were conducted in this region from 2004 to 2007, as shown in detail in Table 1.

\subsection{Pigment measurements}

Methods for pigment sample processing and storage were described in Pan et al. (2008). Pigment samples were analyzed at the Horn Point Laboratory (University of Maryland Center for Environment Science) by reverse-phase high-performance liquid chromatography (HPLC) with a C8 column on the HPLC system equipped with photodiode array detector (Van Heukelem \& Thomas, 2001). The selected primary pigments analyzed in this paper include: total chlorophyll $a$ (TChl_a; the sum of monovinyl Chl_a, divinyl Chl_ $a$, and chlorodide $a$ ), total chlorophyll $b$ (TChl_ $b$; the sum of monovinyl Chl_b and divinyl Chl_b), total chlorophyll $c$ (TChl_c; the sum of Chl_c1, Chl_c2, and Chl_c3), carotene (Caro), fucoxanthin (Fuco), peridinin (Perid), zeaxanthin (Zea), alloxanthin (Allo), diadinoxanthin plus diatoxanthin (Dia), 19'-Butanoyloxyfucoxanthin (But-Fuco), and 19'-Hexanoyloxyfucoxanthin (Hex-Fuco). Prasinoxanthin (Pras) was typically below the level of detection for our data set. Total pigment (TPig) is equal to the sum of the above pigments in this paper (Hooker et al., 2005). Tertiary pigments, such as lutein (Lut), neoxanthin (Neo), and violaxanthin (Viola), were also analyzed. The abbreviations of analyzed pigments are also shown in Table 2.

\subsection{Ocean $R_{r s}$ measurements}

An in-water high-resolution Profiling Reflectance Radiometer (PRR) manufactured by Biospherical Instruments, Inc. (San Diego,

\section{Table 1}

Field cruises conducted for this study. GoM: Gulf of Maine; NYB: New York Bight; SMAB: southern Middle Atlantic Bight; OCV: Ocean Color Validation cruises; BIOME: Bio-physical Interactions in Ocean Margin Ecosystems cruises; CBP: Chesapeake Bay Plume cruises; $\mathrm{CBH}$ : Chesapeake Bay mouth Hydrological survey cruises; ONR: Office of Naval Research funded outer shelf cruises.

\begin{tabular}{llcl}
\hline Regions & Cruises & b Stations & Periods \\
\hline GoM & GoM1 & $12 / 14$ & 26-30 Apr 2007 \\
& GoM2 & $14 / 17$ & 26-28 May 2007 \\
& ${ }^{\text {a GoM3 }}$ & $6 / 6$ & 6-8 Jun 2007 \\
& GoM4 & $5 / 5$ & 6 Sep 2007 \\
NYB & OCV1 & $19 / 20$ & 5-9 May 2007 \\
& OCV2 & $18 / 22$ & 10-14 Nov 2007 \\
& OCV3 & $8 / 8$ & 21-24 Jul 2008 \\
& a'GoM3 & $6 / 7$ & 6-8 Jun 2007 \\
SMAB & BIOME1 & $5 / 14$ & 30 Mar-1 Apr 2005 \\
& BIOME2 & $19 / 29$ & 26-30 Jul 2005 \\
& BIOME3 & $0 / 26$ & 9-12 May 2006 \\
& BIOME4 & $27 / 31$ & 2-6 Jul 2006 \\
& CBP & $13 / 21$ & 27 May, 3 Nov 2005; 6 Sep, 28 Nov 2006 \\
& CBH & $0 / 35$ & 5 May, 5 Jul, 1 Sep, 15 Oct, 15 Nov 2004; 10 Jan, \\
& & & 26 May, 21 Jun, 19 Aug, 23 Sep 2005 \\
& CONR_Aug96 & $15 / 15$ & 26-30 Aug 1996 \\
& CONR_May97 & $11 / 11$ & 29 May-2 Jun 1997 \\
& 'ONR_Aug97 & $9 / 9$ & 11-15 Aug 1997 \\
& CONR_Sep98 & $9 / 9$ & 21-25 Sep 1998
\end{tabular}

a GoM3 cruise was conducted in both GoM and NYB regions.

b Station number was shown for the measurements of $\mathrm{R}_{\mathrm{rS}} / \mathrm{HPLC}$.

c Source from SeaBASS. 
Table 2

Abbreviations for phytoplankton pigments.

\begin{tabular}{ll}
\hline Abbreviation & Description \\
\hline Chlorophyll & \\
TCh__a & Total chlorophyll $a$ \\
TCh__b & Total chlorophyll $b$ \\
TChl_c & Total chlorophyll $c$ \\
& \\
Photosynthetic caroteiod pigments (PSC) & \\
Caro & Carotene \\
Fuco & Fucoxanthin \\
Perid & Peridinin \\
But-Fuco & 19'-Butanoyloxyfucoxanthin \\
Hex-Fuco & 19'-Hexanoyloxyfucoxanthin \\
BH-Fuco & But-Fuco + Hex-Fuco \\
& \\
Photoprotective carotenoid pigments (PPC) & \\
Diadino & Diadinoxanthin \\
Diato & Diatoxanthin \\
Dia & Diadino + Diato \\
Allo & Alloxanthin \\
Zea & Zeaxanthin \\
Tertiary pigments & \\
Lut & \\
Neo & Lutein \\
Viola & Neoxanthin \\
\hline
\end{tabular}

CA) was used for cruises before July 2006. A more compact and higher sampling resolution instrument called the Submersible Biospherical Optical Profiling System (SuBOPS) was used for cruises during and after July 2006. All the sensors in each sampling system had bands centered at 320, 340, 380, 395, 412, 443, 465, 490, 510, 532, 555, 560, $625,665,670,683,710$, and $780 \mathrm{~nm}$ (each band is $10 \mathrm{~nm}$ wide at fullwidth half maximum). Both sampling systems made vertical profiles of the downward irradiance $\left(E_{\mathrm{d}}\right)$ and upwelling radiance $\left(L_{\mathrm{u}}\right)$, along with simultaneous measurements of the global solar irradiance $\left(E_{\mathrm{s}}\right)$. The above-water remote sensing reflectance $\left(R_{\mathrm{rs}}\right)$ spectra were determined from these three light fields using a data processor in compliance with the Ocean Optics Protocols established for in situ observations in support of ocean color remote sensing measurements (Mueller \& Austin, 1995). The data processor was evaluated in an international round robin (Hooker et al., 2001) and was found to have uncertainties to within the requirements for calibration and validation activities.

A 2nd-order polynomial interpolation was applied to estimate $R_{\mathrm{rs}}$ (547) from 532, 555, and $560 \mathrm{~nm}$, while $R_{\mathrm{rs}}(488)$ and $R_{\mathrm{rs}}(667)$ were assumed equal to their values at 490 and $670 \mathrm{~nm}$. Such deviations were made to match the satellite wavelength bands, e.g. 412, 443, $490,510,555$, and $670 \mathrm{~nm}$ for the Sea-viewing Wide Field-of-view Sensor (SeaWiFS), and 412, 443, 488, 531, 547, $667 \mathrm{~nm}$ for the Moderate Resolution Imaging Spectrometer in Aqua (MODIS-Aqua). In-water radiometry measurements were not collected on the Chesapeake Bay mouth Hydrological survey cruises (CBH) or the Bio-physical Interactions in Ocean Margin Ecosystems cruises (BIOME) during 9 to 12 May 2006 (BIOME3) (Table 1). Several data points collected within Delaware Bay during the BIOME4 cruise (Stations 28-31) were excluded for analysis due to the high variability of $R_{\mathrm{rs}}$ measurements among multiple casts at each station caused by the unusually high river discharge rates. Data from a very turbid station $\left(-74.02^{\circ} \mathrm{W}, 40.73^{\circ} \mathrm{N}\right.$; within the Hudson River adjacent to Manhattan, New York) during the Ocean Color Validation cruises (OCV) conducted from 5 to 9 May 2007 (OCV1), whose absorption coefficients of phytoplankton $\left(a_{\mathrm{ph}}\right)$, non-pigmented particles $\left(a_{\mathrm{d}}\right)$, and colored dissolved organic matter $(\mathrm{CDOM})\left(a_{\mathrm{g}}\right)$ at $442 \mathrm{~nm}$ were 0.135 , 1.557, and $0.856 \mathrm{~m}^{-1}$ and [TChl_a] $=0.720 \mathrm{mg} \mathrm{m}^{-3}$, was also excluded from our analysis due to its extremely high ratio of nonpigment particle concentration to phytoplankton.

\subsection{Additional HPLC and AOP data sets}

A set of HPLC and $\mathrm{R}_{\mathrm{rs}}$ data was downloaded from the SeaWiFS Biooptical Archive and Storage System (SeaBASS), which was collected by Dr. Larry Harding's group from the University of Maryland Horn Point Laboratory. The cruises included the Office of Naval Research funded outer shelf cruises (ONR) from 1996 to 1998, which were conducted in the MAB region but excluding those stations inside the Chesapeake and Delaware Bays (Table 1 ). $R_{\mathrm{rs}}$ spectra were measured at $412,443,455,490,510,532,555,565,590,625,670,684$, and $700 \mathrm{~nm}$. Similarly, the $R_{\mathrm{rs}}(488)$ and $R_{\mathrm{rs}}(667)$ were assumed equal to those at 490 and $670 \mathrm{~nm}$, respectively. $R_{\mathrm{rs}}(547)$ was estimated from a 2nd-order polynomial interpolation of $R_{\mathrm{rs}}(532), R_{\mathrm{rs}}(555)$, and $R_{\mathrm{rs}}$ (565) field measurements. In total, data from 196 stations that included both HPLC pigments and $R_{\mathrm{rs}}$ measurements were used to develop pigment algorithms, 37 of which from the GoM region, 51 from the NYB region, and 108 from the SMAB region (Table 1).

In addition, HPLC pigment data collected in the GoM from a series of monthly cruises from 2004 to 2007 and measured by the University of New Hampshire Coastal Ocean Observing Center (UNH) (source from http://www.cooa.unh.edu/data/boats/bottle/) were applied for comparative purposes with our time-series of satellite-derived pigments. The UNH data set was not included in the development of

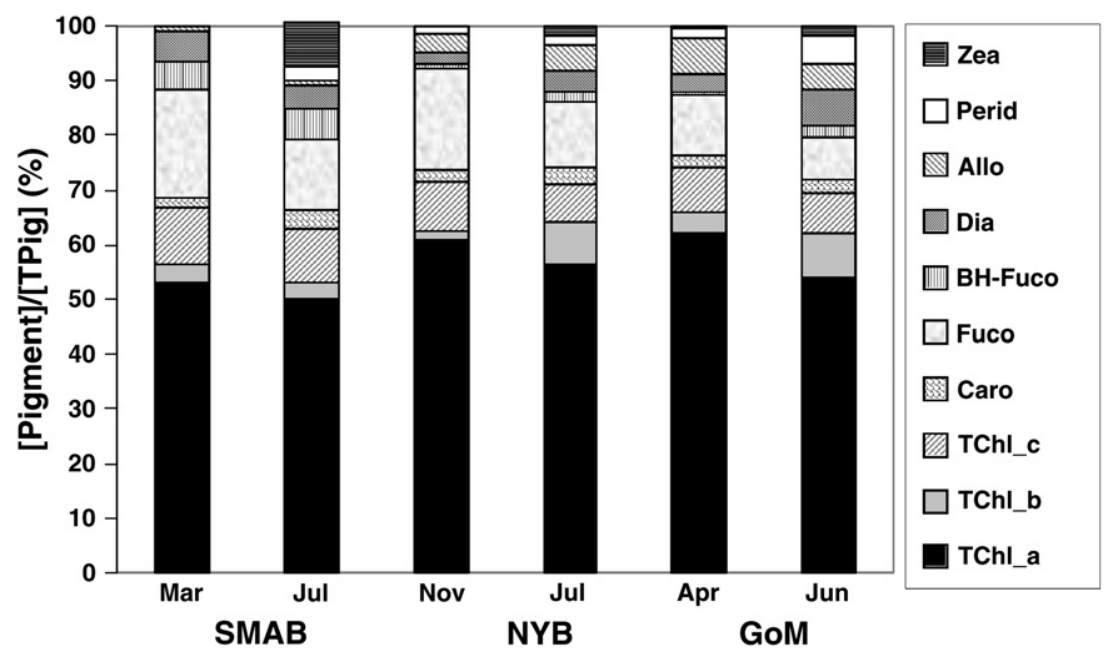

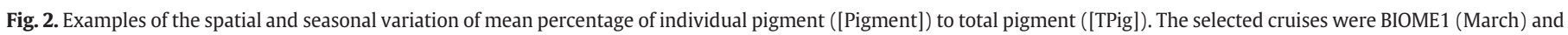
BIOME2 (July) from the SMAB, OCV2 (November) and OCV3 (July) from the NYB, and GoM1 (April) and GoM3 (June) from the GoM sub-regions, respectively. 
Table 3

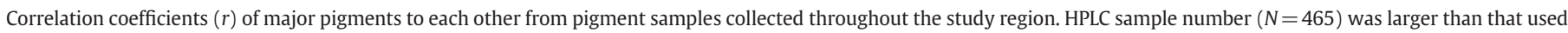
for algorithm development $(N=196)$ since it included stations without radiometry measurements and there were $1-3$ samples at different depths for each station.

\begin{tabular}{|c|c|c|c|c|c|c|c|c|c|c|c|}
\hline Pigments & TChl_a & TChl_b & TChl_c & Caro & Dia & Allo & Fuco & Perid & Zea & Lut & $\mathrm{Neo}$ \\
\hline TChl_b & 0.51 & & & & & & & & & & \\
\hline TChl_c & 0.97 & 0.42 & & & & & & & & & \\
\hline Caro & 0.88 & 0.67 & 0.77 & & & & & & & & \\
\hline Dia & 0.85 & 0.34 & 0.86 & 0.68 & & & & & & & \\
\hline Allo & 0.71 & 0.71 & 0.63 & 0.70 & 0.53 & & & & & & \\
\hline Fuco & 0.93 & 0.28 & 0.93 & 0.70 & 0.81 & 0.53 & & & & & \\
\hline Perid & 0.48 & 0.37 & 0.55 & 0.46 & 0.53 & 0.29 & 0.26 & & & & \\
\hline Zea & 0.17 & 0.26 & 0.02 & 0.57 & 0.02 & 0.01 & 0.01 & 0.08 & & & \\
\hline Lut & 0.41 & 0.88 & 0.30 & 0.62 & 0.33 & 0.61 & 0.20 & 0.25 & 0.40 & & \\
\hline Neo & 0.62 & 0.96 & 0.55 & 0.75 & 0.49 & 0.73 & 0.37 & 0.53 & 0.27 & 0.85 & \\
\hline Viola & 0.59 & 0.95 & 0.52 & 0.72 & 0.47 & 0.73 & 0.34 & 0.51 & 0.25 & 0.84 & 0.95 \\
\hline
\end{tabular}

pigment algorithms due to the unavailability of $R_{\mathrm{rs}}$ field measurements. Furthermore, the UNH data set was not included in the pigment correlation analysis, because the HPLC pigment analysis was accomplished using different methodologies at each institution (Horn Point Laboratory versus the University of New Hampshire). The UNH data set, however, proved useful for evaluating the performance of satellite-derived pigments, especially for the time-series comparisons.

\subsection{Algorithm development and validations}

Similar to the operational TChl_a algorithms, OC4V4 and OC3M (O'Reilly et al., 1998, 2000), we adapted a set of 3rd-order polynomial
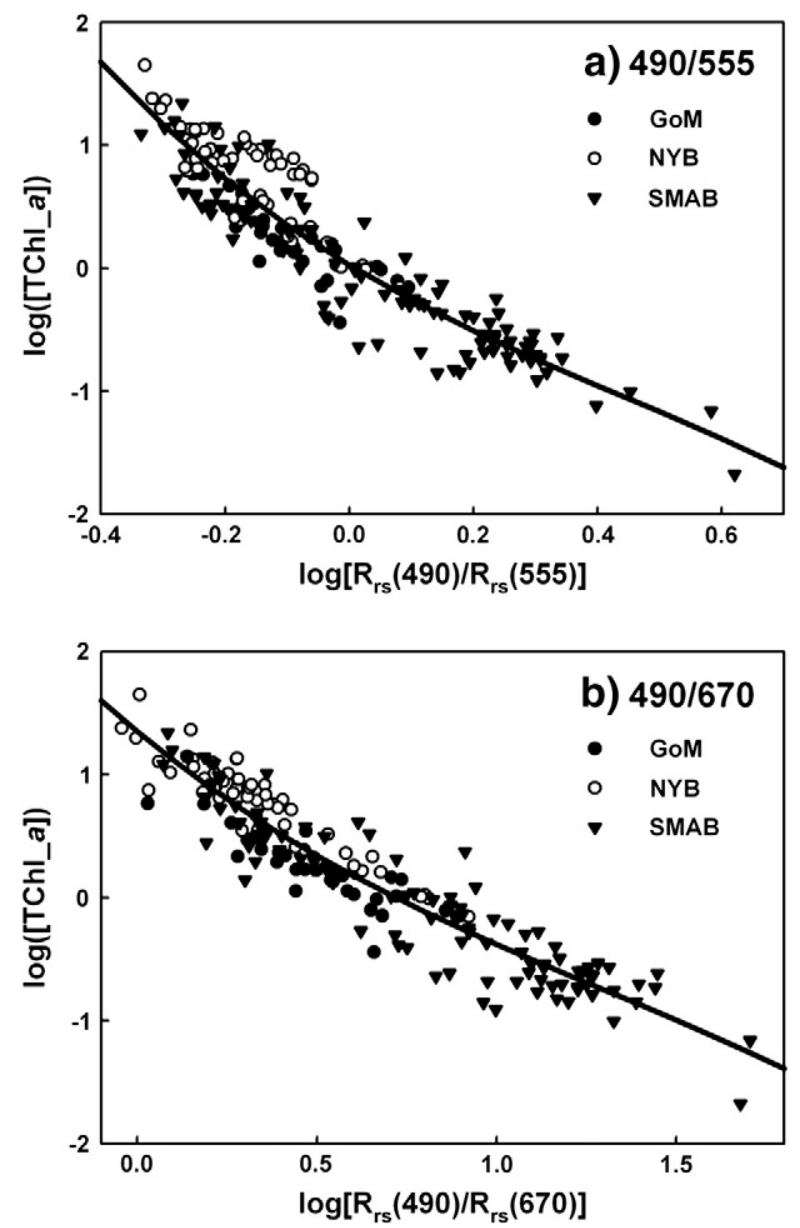

Fig. 3. Examples of algorithm development for total chlorophyll a concentration ([TChl_a]) from $\log [$ Pigment $]=A_{0}+A_{1} X+A_{2} X^{2}+A_{3} X^{3}$, where a) $X=\log \left[R_{\mathrm{rs}}(490) / R_{\mathrm{rs}}\right.$ (555)] and b) $X=\log \left[R_{\mathrm{rs}}(490) / R_{\mathrm{rs}}(670)\right]$. The solid lines represent the polynomial curve fits to the data. functions to develop algorithms for individual pigment concentrations ([Pigment]) from $R_{\mathrm{rs}}$ ratios:

$\log [$ Pigment $]=A_{0}+A_{1} X+A_{2} X^{2}+A_{3} X^{3}$.

Here $X=\log \left[R_{\mathrm{rS}}\left(\lambda_{1}\right) / R_{\mathrm{rs}}\left(\lambda_{2}\right)\right]$, and $A_{i}(i=0,1,2$, or 3$)$ were derived coefficients for each pigment. The 3rd-order functions provide similar regressions to the 4th-order ones but avoid significant errors when extending our algorithms to much clearer or more turbid waters. The selected $\lambda_{1}$ was $490 \mathrm{~nm}$ for SeaWiFS or $488 \mathrm{~nm}$ for MODIS-Aqua. The selected $\lambda_{2}$ for SeaWiFS was 555 or $670 \mathrm{~nm}$ and, 547 or $667 \mathrm{~nm}$ for MODIS-Aqua. Shorter wavelengths (e.g. 412 and $443 \mathrm{~nm}$ ) were not considered in this study due to their relatively high uncertainty from

Table 4

Derived coefficients for pigment algorithms from Eq. (1): $\log [$ Pigment $]=A_{0}+A_{1} X+A_{2} X^{2}+$ $A_{3} X^{3}$, where $X=\log \left[R_{\mathrm{rs}}\left(\lambda_{1}\right) / R_{\mathrm{rs}}\left(\lambda_{2}\right)\right]-1.5 \log \left(T_{\mathrm{w}}\right)$ for Zea, but $X=\log \left[R_{\mathrm{rs}}\left(\lambda_{1}\right) / R_{\mathrm{rs}}\left(\lambda_{2}\right)\right]$ for other pigments. Total data points $N=196$. A set of 2 nd-order polynomial functions replaced the 3rd-order polynomial functions for Fuco due to their similar regression results and more reasonable performance.

\begin{tabular}{|c|c|c|c|c|c|c|c|}
\hline Pigments & $\lambda_{1} / \lambda_{2}$ & $A_{0}$ & $A_{1}$ & $A_{2}$ & $A_{3}$ & $r^{2}$ & RMSE \\
\hline \multicolumn{8}{|c|}{ Group_A pigments } \\
\hline \multirow[t]{3}{*}{ TChl_a } & $490 / 555$ & 0.02534 & -3.033 & 2.096 & -1.607 & 0.86 & 0.244 \\
\hline & $488 / 547$ & 0.03664 & -3.451 & 2.276 & -1.096 & 0.83 & 0.261 \\
\hline & $490 / 670$ & 1.351 & -2.427 & 0.9395 & -0.2432 & 0.89 & 0.217 \\
\hline \multirow[t]{3}{*}{ TChl_c } & $490 / 555$ & -0.7750 & -3.071 & 0.7940 & -1.559 & 0.81 & 0.302 \\
\hline & $488 / 547$ & -0.7584 & -3.511 & 0.4116 & -0.4283 & 0.79 & 0.314 \\
\hline & $490 / 670$ & 0.4424 & -2.291 & 1.190 & -0.5307 & 0.82 & 0.293 \\
\hline \multirow[t]{3}{*}{ Caro } & $490 / 555$ & -1.344 & -2.604 & 3.050 & -3.351 & 0.84 & 0.232 \\
\hline & $488 / 547$ & -1.341 & -2.952 & 3.802 & -4.256 & 0.82 & 0.245 \\
\hline & $490 / 670$ & -0.01909 & -2.775 & 1.703 & -0.5496 & 0.86 & 0.212 \\
\hline \multirow[t]{3}{*}{ Fuco } & $490 / 555$ & -0.6334 & -3.533 & 1.317 & - & 0.77 & 0.356 \\
\hline & $488 / 547$ & -0.6208 & -3.928 & 1.339 & - & 0.75 & 0.373 \\
\hline & $490 / 670$ & 0.6908 & -2.053 & 0.2658 & - & 0.77 & 0.346 \\
\hline \multicolumn{8}{|c|}{ Group_B pigments } \\
\hline \multirow[t]{2}{*}{ TChl_b } & $490 / 555$ & -1.101 & -1.993 & 0.9228 & -7.980 & 0.70 & 0.294 \\
\hline & $488 / 547$ & -1.097 & -2.348 & 0.9633 & -9.374 & 0.69 & 0.299 \\
\hline \multirow[t]{3}{*}{ Allo } & $490 / 555$ & -1.402 & -4.114 & -0.9104 & 0.9988 & 0.72 & 0.384 \\
\hline & $488 / 547$ & -1.401 & -4.816 & -1.264 & 5.838 & 0.71 & 0.391 \\
\hline & $490 / 670$ & 0.04234 & -2.747 & 1.562 & -0.8771 & 0.77 & 0.345 \\
\hline \multirow[t]{2}{*}{ Dia } & $490 / 555$ & -1.001 & -2.626 & 1.501 & -3.736 & 0.74 & 0.310 \\
\hline & $488 / 547$ & -0.9963 & -3.113 & 1.635 & -2.164 & 0.72 & 0.318 \\
\hline \multirow[t]{3}{*}{ Perid } & $490 / 555$ & -1.416 & -2.363 & 2.565 & -4.186 & 0.64 & 0.352 \\
\hline & $488 / 547$ & -1.401 & -2.817 & 2.634 & -2.396 & 0.62 & 0.365 \\
\hline & $490 / 670$ & -0.01038 & -3.807 & 3.612 & -1.489 & 0.70 & 0.327 \\
\hline \multirow[t]{2}{*}{ Lut } & $490 / 555$ & -2.196 & -1.935 & 2.042 & -3.601 & 0.53 & 0.314 \\
\hline & $488 / 547$ & -2.188 & -2.037 & 2.179 & -10.16 & 0.53 & 0.313 \\
\hline \multirow[t]{2}{*}{ Neo } & $490 / 555$ & -1.984 & -1.790 & 1.610 & -11.31 & 0.73 & 0.239 \\
\hline & $488 / 547$ & -1.983 & -2.151 & 2.134 & -12.67 & 0.70 & 0.251 \\
\hline \multirow[t]{2}{*}{ Viola } & $490 / 555$ & -1.950 & -1.285 & 2.595 & -14.65 & 0.67 & 0.273 \\
\hline & $488 / 547$ & -1.947 & -1.601 & 3.258 & -17.31 & 0.63 & 0.285 \\
\hline \multicolumn{8}{|c|}{ Group_C pigment } \\
\hline \multirow[t]{2}{*}{ Zea } & $490 / 555$ & -11.58 & -17.94 & -11.02 & -2.323 & 0.65 & 0.293 \\
\hline & $488 / 547$ & -9.885 & -14.84 & -9.230 & -1.998 & 0.64 & 0.296 \\
\hline
\end{tabular}


satellite observations (unpublished data), as also concluded by Antoine et al. (2008). $R_{\mathrm{rs}}$ band ratios based on other wavelengths such as $510 \mathrm{~nm}$ and $532 \mathrm{~nm}$, which typically provided similar $r^{2}$ to band ratios based on 490 or $488 \mathrm{~nm}$, are not discussed in this paper. The algorithms applied for satellite data analysis were selected based on higher $r^{2}$ and lower root mean square error (RMSE; see the definition in next section) from Eq. (1).

\subsection{Satellite imagery and validation}

SeaWiFS and MODIS-Aqua observations of $R_{\mathrm{rs}}(\lambda)$ and [TChl_a] were processed from Level 1 to Level 2 using the SeaWiFS Data Analysis System software (SeaDAS version 5.2.0 and $12 \mathrm{gen}$ version 5.8.3). The nighttime sea-surface temperatures (SST4) calculated from MODIS-Aqua short-wave infrared (3.959 and $4.050 \mu \mathrm{m}$ ) observations were obtained to represent bulk water temperatures. The water temperatures represented by SST4 were necessary to derive [Zea] from satellite data (see the detail in Section 3.2). The methods for satellite validation of phytoplankton pigments were described in Mannino et al. (2008) and Pan et al. (2008) following Bailey and Werdell (2006) protocols. Two sets of satellite overpass time windows, 3 and $8 \mathrm{~h}$, were set to allow for inclusion of sufficient data points in the analysis. Since the field data demonstrated that properties within the bays and river mouths were subject to significant variation (even within $30 \mathrm{~min}$ ) during summer, we excluded those stations from the satellite validation. The mean absolute percent difference (MAPD) and log-transformed root mean square error (RMSE) between the modeled products $\left(C_{\mathrm{alg}}\right)$ and field measurements $\left(C_{\text {field }}\right)$ were calculated as:

$\operatorname{MAPD}(\%)=\frac{\sum\left|\left(C_{\mathrm{alg}}-C_{\text {field }}\right) / C_{\text {field }}\right|}{N} \times 100$

$R M S E=\sqrt{\sum\left[\log \left(C_{\text {alg }}\right)-\log \left(C_{\text {field }}\right)\right]^{2} / N}$.

Here $N$ represents the number of samples.

\section{Results}

\subsection{Phytoplankton pigment distribution from field data}

The seasonal and regional variation of phytoplankton pigment composition is apparent, as shown in Fig. 2. TChl_a is the most abundant pigment accounting for $50-62 \%$ of total pigment (Fig. 2). Fuco is commonly used as a pigment biomarker for diatoms in this region (Adolf et al., 2006; Jeffrey et al., 1997), and is the most abundant carotenoid pigment during all seasons and within all regions (Fig. 2). The significant decrease of the Fuco fraction from winter-spring to summer (Fig. 2) coincided with the seasonal variation of diatoms in this region. For example, the dominant phytoplankton community shifts from diatoms during winter-spring to a mixture of diatoms, cryptophytes, dinoflagellates, and cyanobacteria during summer in the SMAB (Adolf et al., 2006; Marshall \& Cohn, 1983; Marshall et al., 2006). The significant increase of certain biomarker pigments during summer, such as Zea in the SMAB region, BH-Fuco and Dia in the NYB region, and Perid in the GoM region, implies that cyanobacteria, chrysophytes, and peridinin-containing dinoflagellate blooms may occur during summer in these sub-regions respectively (Fig. 2; ECOHAB, 1994).

\subsection{Pigment algorithm development}

Phytoplankton pigments were separated into three groups for algorithm development based on the correlation coefficients $(r)$ of

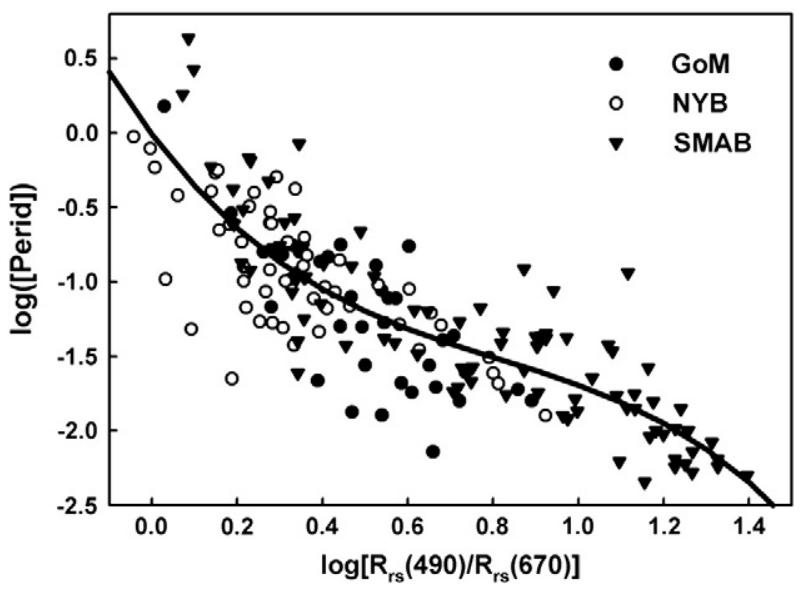

Fig. 4. Algorithm development for peridinin concentration ([Perid]). See Fig. 3 for detailed description.

pigments to TChl_a (Table 3): Group_A $(r \geq 0.8)$, Group_B $(0.4 \leq r<0.8)$, and Group_C $(r<0.4)$. The only exception was Dia whose $r=0.85$ but was included in Group_B instead of Group_A based on the consideration of phytoplankton species distribution and their relative pigment concentrations, as shown in detail below. Algorithms for pigments whose concentrations were typically very low in this study region and yielded poor relationships, such as But-Fuco, Hex-Fuco, and Pras, were not included in this study.
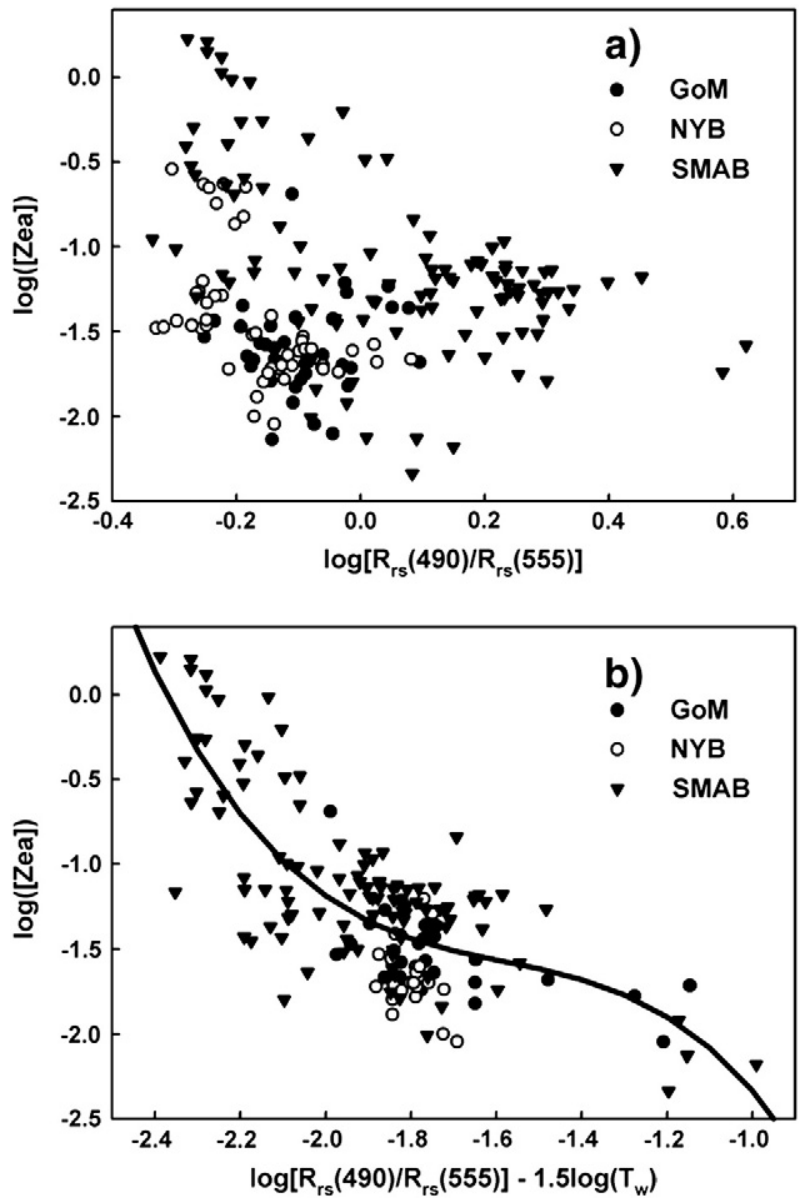

Fig. 5. Algorithm development for zeaxanthin concentration ([Zea]). See Fig. 3 for detailed description. The independent parameters $(X)$ in Eq. (1) shown here are a) $X=\log \left[R_{\mathrm{rs}}(490) / R_{\mathrm{rs}}(555)\right]$ and b) water temperature $\left(T_{\mathrm{w}}\right)$ modified value as $X=\log$ $\left[R_{\mathrm{rs}}(490) / R_{\mathrm{rs}}(555)\right]-1.5 \log \left(T_{\mathrm{w}}\right)$. 
Group_A pigments include TChl_a, TChl_c, Caro, and Fuco, which are relatively abundant in diatoms (Jeffrey et al., 1997). Although Dia is also abundant in diatoms, it is not included in this group since its relative concentration per TChl_a unit in diatoms is typically much lower than that in other phytoplankton (e.g. dinoflagellates, haptophytes, and chrysophytes) (Mackey et al., 1996; Lewitus et al., 2005). The algorithm performance for Dia was more similar to Group_B pigments than to Group_A pigments from our data set (data not shown). Except for Caro, the pigments in this group were highly correlated to each other $(r>0.93)$ (Table 3). Caro was highly correlated to TChl_a $(r=0.88)$ but less correlated to Fuco $(r=0.70)$ and TChl_c $(r=0.77)$, since Caro is much less abundant in diatoms than Fuco and TChl_c (Jeffrey et al., 1997). Algorithms for Group_A pigments based on the $R_{\mathrm{rs}}$ band ratios such as $R_{\mathrm{rs}}(490) / R_{\mathrm{rs}}$ (555), yielded weaker relationships than $R_{\mathrm{rs}}(490) / R_{\mathrm{rs}}(670)$. Algorithms based on $R_{\mathrm{rs}}(490) / R_{\mathrm{rs}}(555)$ were subject to more regional and temporal variation and yielded significant underestimation of Group_A pigments for stations (e.g. from OCV2 cruise) with relatively low percentages of absorption from CDOM (unpublished data) and carotenoid pigments (Fig. 3a). Algorithms based on $R_{\mathrm{rs}}(490) / R_{\mathrm{rs}}(670)$ were subject to less variation of water constituents and phytoplankton species composition (Fig. 3b). The absorption at $490 \mathrm{~nm}$ is contributed mostly from CDOM, detrital particles, and carotenoid pigments, while chlorophyll pigments along with water molecules contribute most of the absorption at $670 \mathrm{~nm}$ (Bricaud et al., 2007; Pope \& Fry, 1997). Thus, the ratio of $R_{\mathrm{rs}}(490) /$ $R_{\mathrm{rs}}(670)$ may provide better information on the relative concentration of chlorophyll and carotenoid pigments. Since the satellite-derived $R_{\mathrm{rs}}$ at longer wavelengths (e.g. $670 \mathrm{~nm}$ ) may contain significant uncertainty (e.g. MAPD $=71.4 \%$ for match-up comparison for SeaWiFS \pm 3 h overpass window; also shown in Antoine et al., 2008), we applied the following method to derive this group of pigments from satellite imagery $\left(C_{\text {sat }}\right)$.

a). If $R_{3 / 5}>0.15$ or $R_{6}<0.0001$, then $C_{\text {sat }}=C_{3 / 5}$;

b). Otherwise, $C_{\mathrm{sat}}=\max \left(C_{3 / 5}, C_{3 / 6}\right)$.
Here, $R_{3 / 5}$ and $R_{6}$ represent $R_{\mathrm{rS}}(490) / R_{\mathrm{rS}}(555)$ and $R_{\mathrm{rS}}(670)$ for SeaWiFS, or $R_{\mathrm{rs}}(488) / R_{\mathrm{rs}}(547)$ and $R_{\mathrm{rs}}(667)$ for MODIS-Aqua, respectively. $C_{3 / 5}$ and $C_{3 / 6}$ represent the pigment concentrations calculated from the band ratios of $R_{\mathrm{rS}}(490) / R_{\mathrm{rs}}(555)$ and $R_{\mathrm{rS}}(490) / R_{\mathrm{rS}}(670)$ for SeaWiFS, or $R_{\mathrm{rs}}(488) / \mathrm{R}_{\mathrm{rs}}(547)$ and $R_{\mathrm{rs}}(488) / R_{\mathrm{rs}}(667)$ for MODIS-Aqua, respectively. $R_{3 / 5}>0.15$ typically represents stations where the waters are relatively clear and the low signal-to-noise ratio typically yields high errors in $R_{\mathrm{rs}}(670)$ or $R_{\mathrm{rs}}(667)$. Field measurements showed that $R_{\mathrm{rs}}(670)$ was seldom $<0.0001$, occurring only 5 of 196 stations from our data set. $R_{6}<0.0001$ typically refers to clearer waters or regions where there is an over-correction of the atmospheric contribution to the top-of-the atmospheric radiances measured by the satellite sensors. The algorithms for Group_A pigments are shown in Table 4.

Group_B pigments include TChl_b, Allo, Perid, Dia, Lut, Neo, and Viola, which are relatively abundant in phytoplankton other than diatoms (Jeffrey et al., 1997), and whose distribution is not significantly affected by the water temperature $\left(T_{\mathrm{w}}\right)$. The algorithm performances for Group_B pigments were not significantly different over the water temperature gradients (e.g. $<5,5-10,10-15,15-20$, and $>20^{\circ} \mathrm{C}$ ) (data not shown). Accessory pigments abundant in green algae (e.g. chlorophytes and prasinophytes), such as TChl_b, Lut, Neo, and Viola, were highly correlated to each other ( $r=0.84$ to 0.95 ) (Table 3). The species-specific pigments, such as Allo (which is specific to cryptophytes) and Perid (which is specific to peridinincontaining dinoflagellates), were typically less correlated to other pigments (Table 3 ). The algorithms for these pigments were typically less robust than those for Group_A pigments (Table 4 and Fig. 4). Unlike the Group_A pigments, algorithms for the Group_B pigments are less subject to regional and temporal variation (Fig. 4). For this group of pigments, the $R_{\mathrm{rs}}(490) / R_{\mathrm{rs}}(555)$ or $R_{\mathrm{rs}}(488) / R_{\mathrm{rs}}(547)$ yielded stronger relationships with TChl_b, Dia, Lut, Neo, and Viola, while the $R_{\mathrm{rS}}(490) / R_{\mathrm{rs}}(670)$ based algorithms proved better for retrieval of Allo and Perid. Considering the lower accuracy level of $R_{\mathrm{rs}}(670)$ or

Table 5

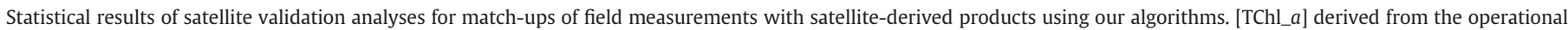

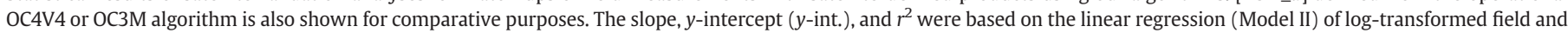
satellite-derived pigment concentrations.

\begin{tabular}{|c|c|c|c|c|c|c|c|c|c|c|}
\hline \multirow[t]{2}{*}{ Pigment } & \multicolumn{5}{|c|}{ \pm 3 h overpass windows } & \multicolumn{5}{|c|}{ \pm 8 h overpass windows } \\
\hline & MAPD (SD) & RMSE & Slope & $y$-int. & $r^{2}$ & MAPD (SD) & RMSE & Slope & $y$-int. & $r^{2}$ \\
\hline \multicolumn{11}{|c|}{ SeaWiFS ( $N=29$ and 55 for \pm 3 and $8 h$ overpass windows, respectively) } \\
\hline OC4V4 & $77.7(71.7)$ & 0.289 & 0.677 & 0.164 & 0.94 & $68.7(61.5)$ & 0.269 & 0.700 & 0.163 & 0.89 \\
\hline TChl_a & $29.9(26.3)$ & 0.189 & 0.870 & -0.041 & 0.95 & $36.3(27.2)$ & 0.207 & 0.945 & -0.0436 & 0.90 \\
\hline TChl_b & $37.3(21.6)$ & 0.270 & 0.762 & -0.360 & 0.78 & $43.0(25.2)$ & 0.275 & 0.909 & -0.199 & 0.67 \\
\hline TChl_c & $36.3(26.0)$ & 0.219 & 0.909 & -0.167 & 0.93 & $42.3(29.9)$ & 0.244 & 0.994 & -0.113 & 0.87 \\
\hline Caro & $30.3(22.2)$ & 0.214 & 0.862 & -0.231 & 0.90 & $43.1(42.1)$ & 0.233 & 1.002 & -0.0249 & 0.81 \\
\hline Allo & $54.7(54.4)$ & 0.430 & 0.920 & -0.249 & 0.65 & $61.5(56.8)$ & 0.452 & 1.143 & 0.0003 & 0.53 \\
\hline Fuco & $38.2(28.5)$ & 0.247 & 0.855 & -0.169 & 0.91 & $42.0(30.5)$ & 0.262 & 0.891 & -0.144 & 0.88 \\
\hline Perid & $37.6(35.2)$ & 0.267 & 0.799 & -0.306 & 0.78 & $43.0(40.0)$ & 0.280 & 0.828 & -0.292 & 0.75 \\
\hline Dia & $47.1(31.1)$ & 0.279 & 0.898 & -0.252 & 0.79 & $47.9(32.2)$ & 0.294 & 0.948 & -0.189 & 0.72 \\
\hline Zea & $36.2(24.2)$ & 0.256 & 0.838 & -0.332 & 0.75 & $44.4(30.8)$ & 0.280 & 0.808 & -0.351 & 0.65 \\
\hline Lut & 43.9 (24.9) & 0.289 & 0.687 & -0.777 & 0.66 & 47.6 (34.9) & 0.277 & 0.738 & -0.623 & 0.55 \\
\hline $\mathrm{Neo}$ & $37.8(24.8)$ & 0.272 & 0.782 & -0.524 & 0.70 & 41.5 (23.9) & 0.290 & 0.809 & -0.492 & 0.62 \\
\hline Viola & $42.0(27.9)$ & 0.292 & 0.665 & -0.696 & 0.58 & $36.9(23.9)$ & 0.259 & 0.817 & -0.446 & 0.61 \\
\hline \multicolumn{11}{|c|}{ MODIS-Aqua ( $N=10$ and 17 for \pm 3 and $8 h$ overpass windows, respectively) } \\
\hline OC3M & $49.0(40.7)$ & 0.237 & 0.549 & 0.176 & 0.88 & $60.2(49.6)$ & 0.251 & 0.569 & 0.203 & 0.89 \\
\hline TChl_a & $39.2(19.6)$ & 0.278 & 0.729 & -0.081 & 0.83 & $33.7(18.4)$ & 0.229 & 0.778 & -0.0546 & 0.87 \\
\hline TChl_ $b$ & $49.5(17.4)$ & 0.364 & 0.664 & -0.545 & 0.74 & $45.7(18.1)$ & 0.329 & 0.684 & -0.496 & 0.76 \\
\hline TChl_c & $41.3(26.2)$ & 0.338 & 0.812 & -0.384 & 0.80 & $35.4(22.5)$ & 0.279 & 0.839 & -0.278 & 0.84 \\
\hline Caro & $36.8(22.0)$ & 0.245 & 0.715 & -0.435 & 0.80 & $32.3(19.2)$ & 0.211 & 0.770 & -0.362 & 0.88 \\
\hline Allo & $39.5(28.8)$ & 0.386 & 1.000 & -0.279 & 0.71 & $42.1(27.6)$ & 0.417 & 1.345 & 0.114 & 0.64 \\
\hline Fuco & $44.2(27.3)$ & 0.375 & 0.728 & -0.342 & 0.87 & 40.9 (22.9) & 0.318 & 0.741 & -0.283 & 0.89 \\
\hline Perid & $44.1(36.5)$ & 0.271 & 0.556 & -0.593 & 0.74 & $44.3(33.4)$ & 0.257 & 0.648 & -0.487 & 0.83 \\
\hline Dia & $42.7(15.3)$ & 0.282 & 1.003 & -0.255 & 0.86 & $34.0(19.7)$ & 0.368 & 1.045 & -0.213 & 0.54 \\
\hline Zea & $43.3(20.8)$ & 0.307 & 0.779 & -0.489 & 0.15 & $48.5(22.8)$ & 0.262 & 0.647 & -0.846 & 0.56 \\
\hline Lut & $37.4(21.2)$ & 0.283 & 0.775 & -0.642 & 0.57 & $37.3(22.1)$ & 0.319 & 0.653 & -0.811 & 0.76 \\
\hline $\mathrm{Neo}$ & $49.8(16.3)$ & 0.352 & 0.618 & -0.904 & 0.82 & $45.2(19.6)$ & 0.307 & 0.583 & -0.899 & 0.76 \\
\hline Viola & $47.2(25.5)$ & 0.347 & 0.445 & -1.130 & 0.71 & $43.2(21.7)$ & 0.239 & 1.044 & -0.154 & 0.80 \\
\hline
\end{tabular}


$R_{\mathrm{rs}}(667)$, we applied the following method to derive this group of pigments from satellite imagery $\left(C_{\mathrm{sat}}\right)$.

a). $C_{\text {sat }}=C_{3 / 5}$ for TChl_b, Dia, Lut, Neo, and Viola;

b). If $R_{3 / 5}>0.15$ or $R_{6}<0.0001$, then $C_{\text {sat }}=C_{3 / 5}$ for Allo and Perid. Otherwise, $C_{\text {sat }}=C_{3 / 6}$ for Allo and Perid.

Group_C pigments include Zea, whose distribution is significantly related to water temperature $\left(T_{\mathrm{w}}\right)$. The correlation coefficients for Zea with other pigments were typically low $(r=0.01$ to 0.57$)$ (Table 3 ). Zea is a biomarker pigment for cyanobacteria in coastal waters, which are more dominant in tropical and subtropical regions. Zea is also abundant in prochlorophytes, which are seldom found in this coastal region. Our data show that pigments unique to prochlorophytes, divinyl Chl_a (Jeffrey et al., 1997), were typically below the level of detection on the inner (e.g. defined as bathymetry $<20 \mathrm{~m}$ ) and mid shelf (e.g. defined as bathymetry of 20 to $40 \mathrm{~m}$ ), and comprised up to $4.5 \%$ of [TChl_a] on the outer shelf (e.g. defined as bathymetry of 40 to $200 \mathrm{~m}$ ) with [TChl_a] $<0.3 \mathrm{mg} \mathrm{m}^{-3}$. Without considering the relationships with water temperature, the relationships of [Zea] with $R_{\mathrm{rs}}$ band ratios were relatively poor (Fig. 5a). We therefore modified $X$ in
Eq. (1) as $X=\log \left[R_{\mathrm{rs}}\left(\lambda_{1}\right) / R_{\mathrm{rS}}\left(\lambda_{2}\right)\right]-1.5 \log \left(T_{\mathrm{w}}\right)$ to develop a better performing algorithm for Zea (Fig. 5b and Table 4).

\subsection{Satellite validation}

There were a total of 29 and 55 match-up stations for SeaWiFS \pm 3 and \pm 8 h overpass windows, respectively, and 10 and 17 match-up stations for MODIS \pm 3 and \pm 8 h overpass windows for all field HPLC pigment measurements ( $N=299$, Table 2$)$. Due to insufficient matchup stations, we included stations used for algorithm development in the satellite validation analysis, whose proportions were $13 / 29,17 / 55$, $5 / 10$, and $5 / 17$ for SeaWiFS \pm 3 and \pm 8 , and MODIS \pm 3 and \pm 8 overpass windows, respectively. In terms of algorithm performance, Group_A pigment algorithms yielded better agreements between field measurements of pigments and satellite-derived pigments (Table 5 and Fig. 6). The MAPDs and RMSEs for these pigments were $30-38 \%$ and $0.19-0.25$, respectively, for SeaWiFS within $\pm 3 \mathrm{~h}$ satellite overpass time window, as compared to $36-47 \%$ and $0.25-$ 0.29 for other pigments except for Allo (55\% and 0.43) (Table 5). Similar performance trends were also found for the match-up plots of field measurements versus satellite-derived pigments for SeaWiFS
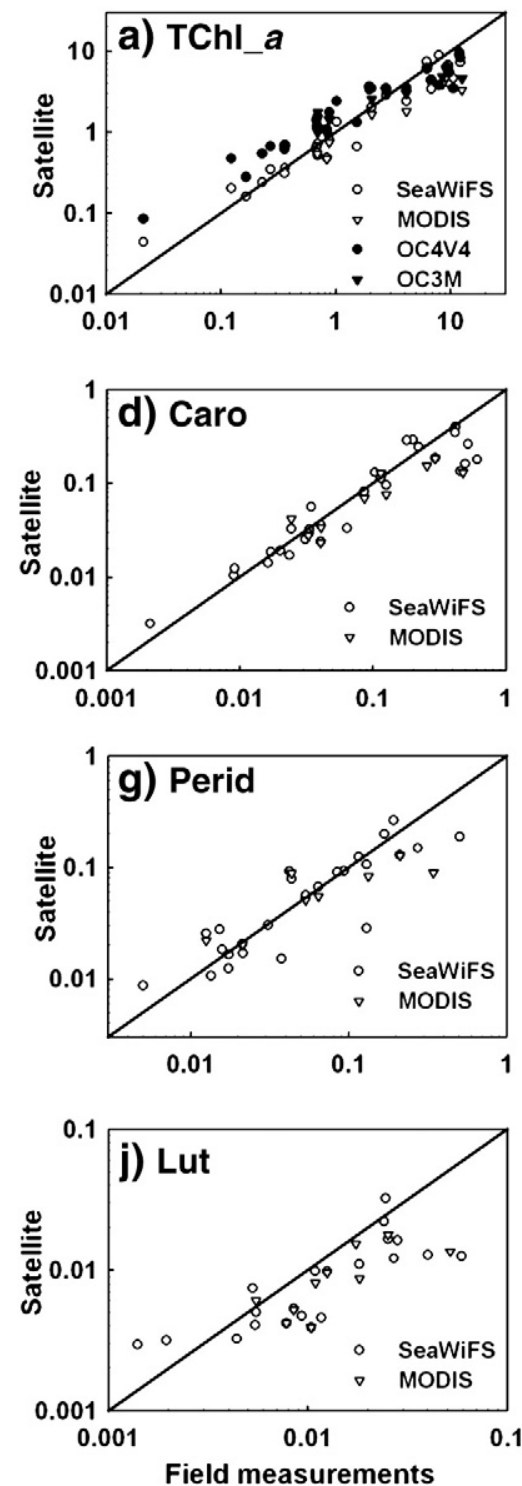
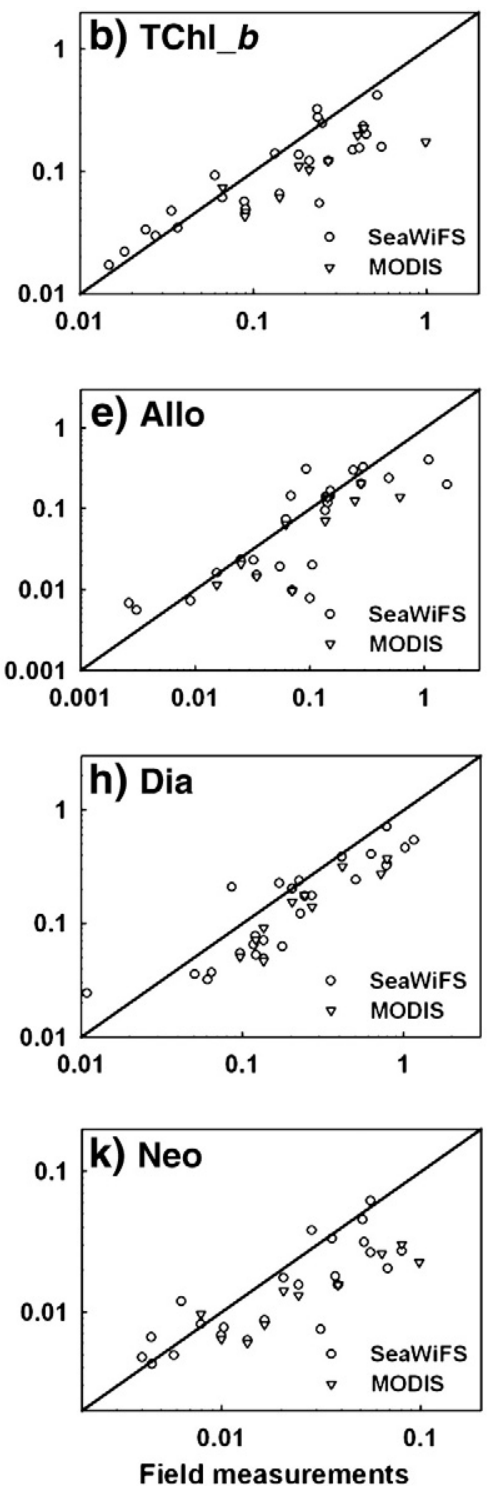
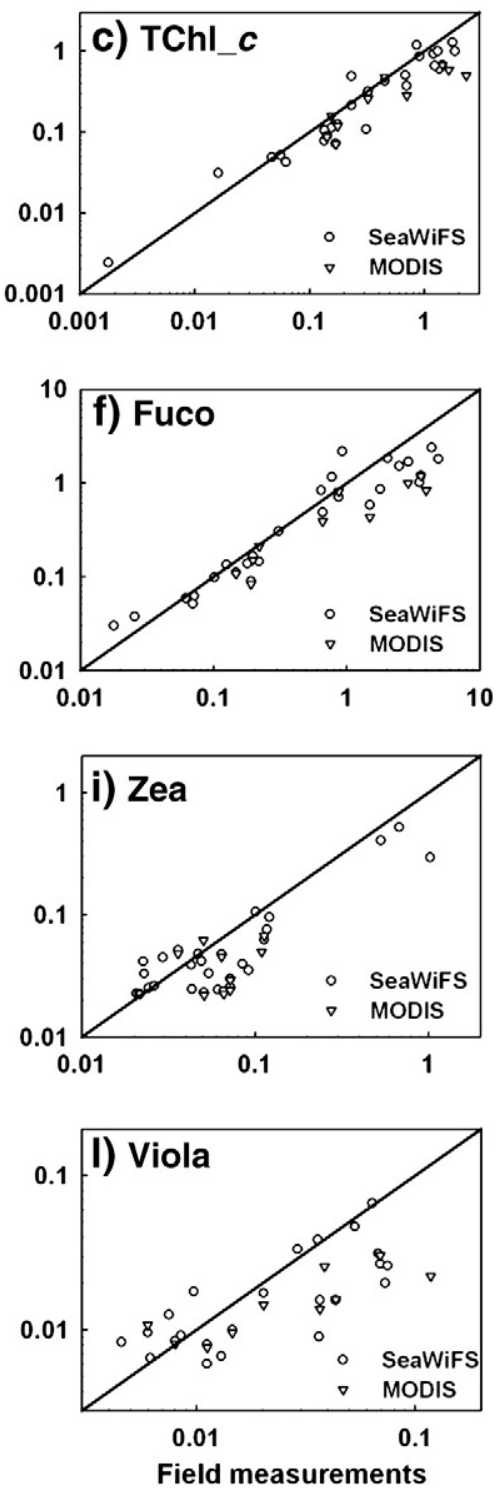

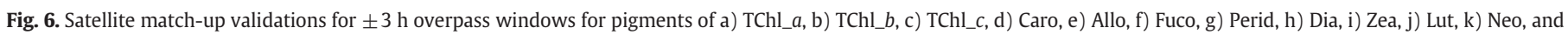
1) Viola. [TChl_a] calculated from OC4V4 and OC3M were also shown for comparisons. The 1:1 values are represented as solid lines. 
(Table 5 and Fig. 6). When the overpass window was extended to $\pm 8 \mathrm{~h}$ for SeaWiFS, higher MAPDs and RMSEs were typically found for all pigments as compared to those with $\pm 3 \mathrm{~h}$ overpass window (Table 5 and Fig. 6). The match-up comparisons for MODIS-Aqua were more difficult due to the limited number of station match-ups ( $N=10$ and 17 for \pm 3 and $8 \mathrm{~h}$ overpass windows, respectively) and high proportion $(>50 \%)$ of match-up stations from the highly variable Chesapeake Bay mouth and plume region. Consequently, the matchup comparisons for MODIS-Aqua typically had higher uncertainty than for SeaWiFS, but the algorithm performance was improved for the \pm 8 h overpass window, presumably due to the inclusion of more stations from outside of the Bay plume region (Table 5 and Fig. 6). Our TChl_ $a$ algorithms seemed to provide similar performance results to those derived from a regional SMAB database (Pan et al., 2008), but significantly better performance than the operational TChl_a algorithms (e.g. OC4V4 and OC3M) (Table 5).

\subsection{Satellite pigment distributions}

The seasonal and spatial variation of pigment distributions was clearly shown on satellite-derived pigment distributions (Fig. 7). Pigment concentrations generally decrease from the inner shelf to outer shelf, and are higher in regions strongly influenced by river discharge (e.g. Chesapeake Bay mouth, Delaware Bay mouth, and
Hudson River Estuary) and lower along the boundary with the Gulf Stream (Fig. 7). Relatively higher pigment concentrations are also found in George's Bank (Fig. 7), which is relatively shallower and tidally well-mixed, due to the upwelling of nutrient-rich waters that support phytoplankton growth (O'Reilly \& Zetlin, 1998). The riverine outflow is one of the most important factors to stimulate algal blooms in our study region (Acker et al., 2005; Harding et al., 2005; O'Reilly \& Zetlin, 1998; Pan et al., 2008). For example, the monthly mean flow rates out of the Chesapeake Bay were 2983, 1463, 729, and $4189 \mathrm{~m}^{3} \mathrm{~s}^{-1}$ for February, May, August, and November 2006, respectively (Source from G. Fisher, U.S. Geological Survey, personal communication, 2007). The higher pigment concentrations consequently extend from near the Chesapeake Bay mouth region in August to more offshore regions in November, February, and even May (Fig. 7). The [TChl_a] distribution calculated from the operational TChl_a algorithms (e.g. OC3M) has similar regional and temporal trends (e.g. winter-spring blooms, and effect from river discharge) to satellite distributions derived from our own algorithms (Fig. 7). The relative percentage of [TChl_a] derived from OC3M normalized to [TChl_a] from our algorithm has a typical value close to $100 \%$ (ratio of 1 ) on the inner shelf, while much higher percentages are found on the outer shelf (Fig. 8). Such differences are consistent with the match-up comparisons (Table 5) and previous work (Pan et al., 2008; Werdell et al., 2009) that demonstrate overestimation of [TChl_a] by the

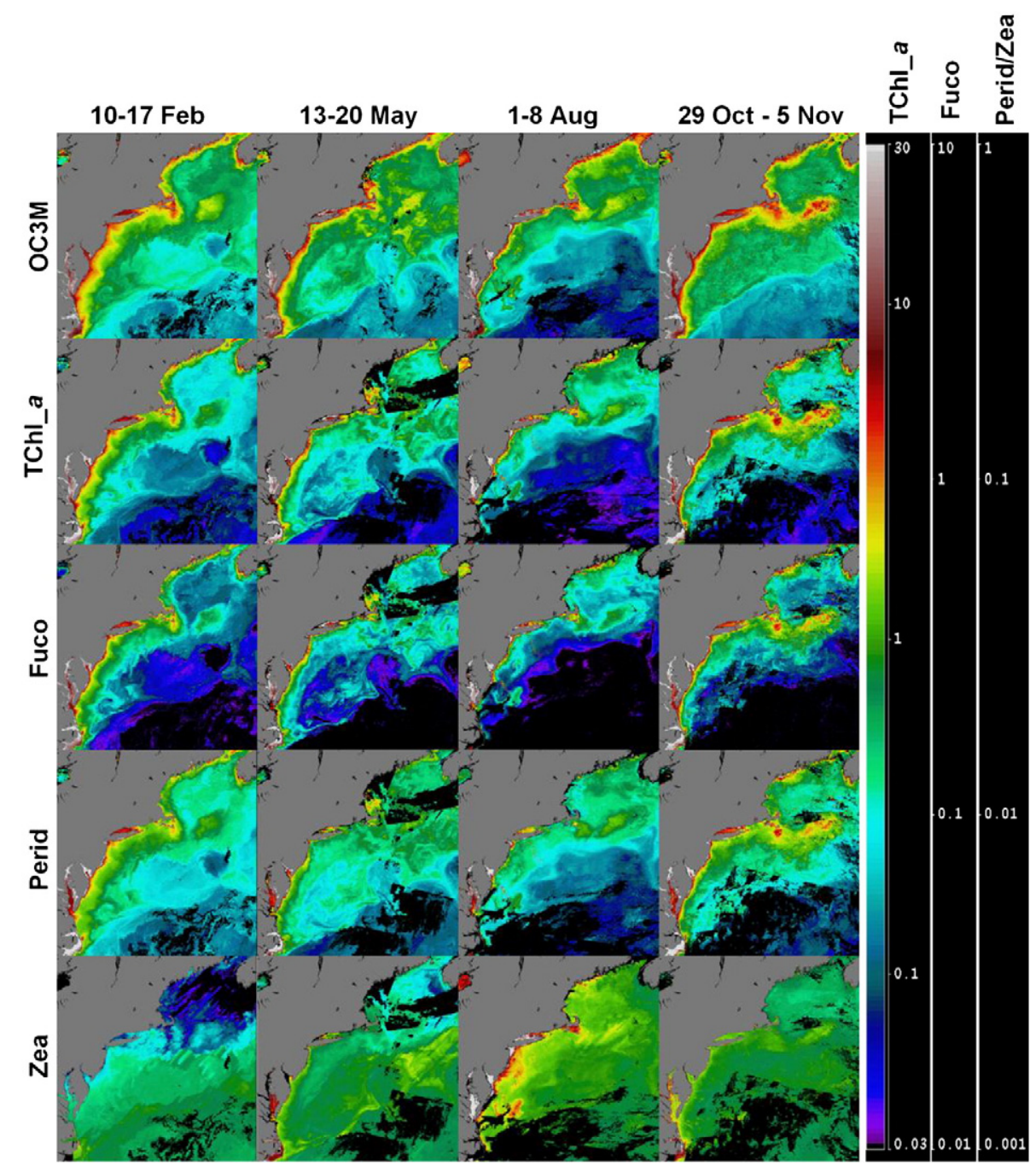

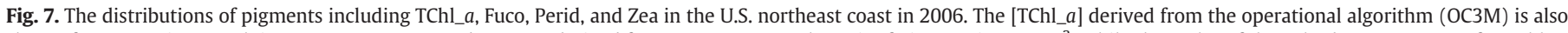

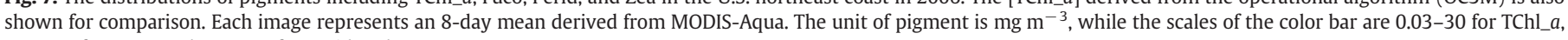
0.01-10 for Fuco, and 0.001-1 for Perid and Zea. 


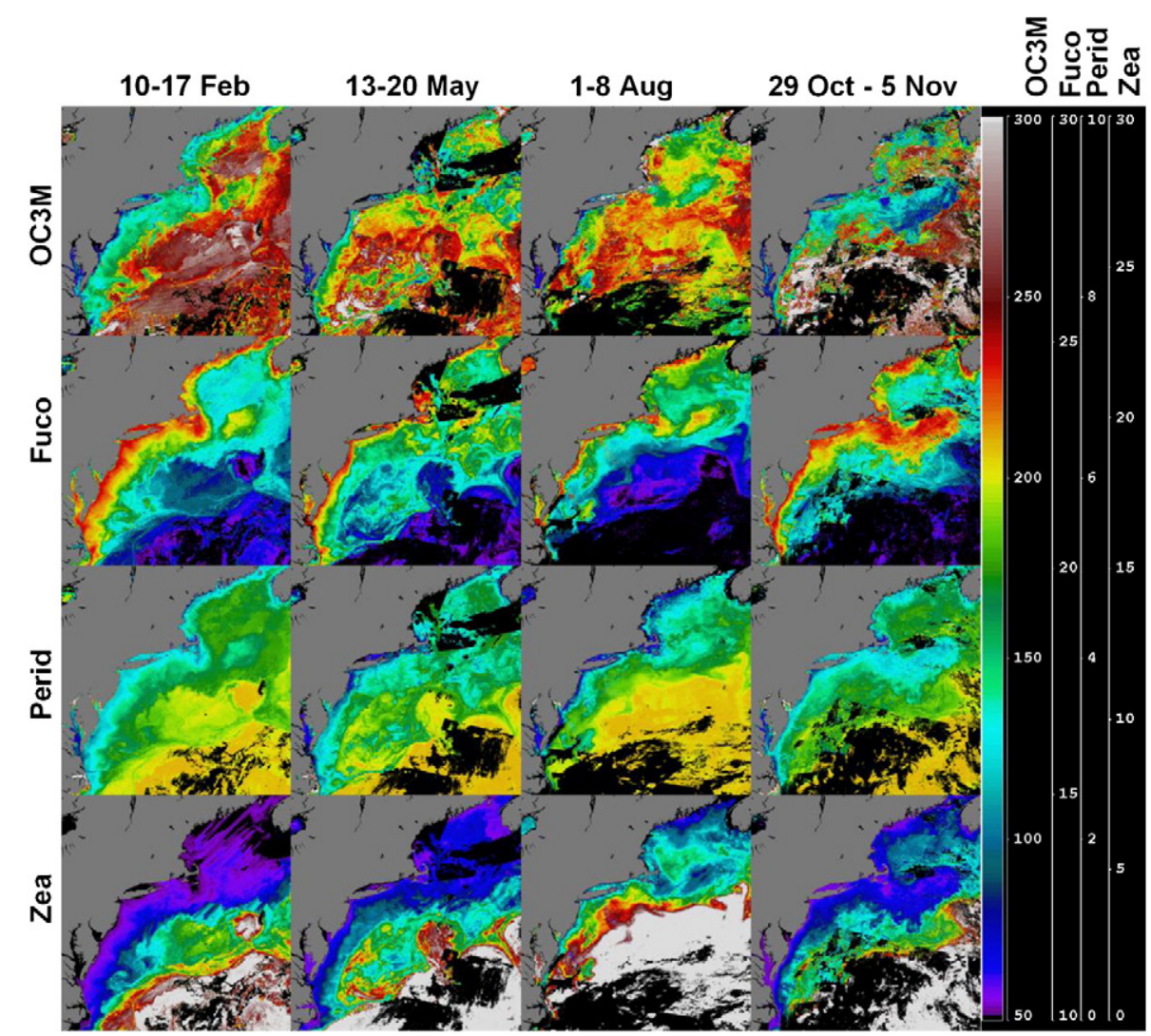

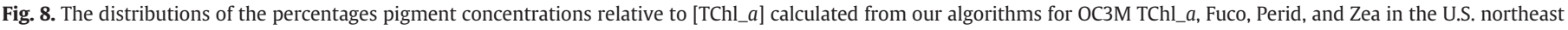
coast in 2006. See Fig. 7 for detailed description. The scales of the color bar are 50-300 (\%) for OC3M, 10-30 (\%) for Fuco, 0-10 (\%) for Perid, and 0-30 (\%) for Zea.

operational algorithms. The distribution of Fuco is generally similar to TChl_a (Fig. 7), which is consistent with previous studies demonstrating that diatoms are typically the most abundant phytoplankton in this region (Marshall \& Cohn, 1983; O'Reilly \& Zetlin, 1998). The distribution of Perid, a pigment unique to peridinin-containing dinoflagellates, is also similar to that of TChl_a (Fig. 7), because TChl_a is also rich in dinoflagellates (Jeffrey et al., 1997) and Perid was partly correlated to TChl_ $a$ in this region $(r=0.48$, Table 3). As indicated from Table 3, the major pigments were all positively correlated to each other, suggesting the occurrence of mixed phytoplankton populations. As a biomarker pigment to cyanobacteria in coastal waters, whose distribution is significantly affected by water temperature (Jeffrey et al., 1997; Reynolds \& Walsby, 1975), [Zea] is typically much lower during winter than during summer. Higher [Zea] is more commonly found in the southern region during summer (Fig. 7).

Relative to [TChl_a], the percentage of [Fuco] typically decreases from high-pigment region to low-pigment region and from winter-spring to summer, while [Perid] and [Zea] have the opposite trends (Fig. 8). Such seasonal and spatial trends of relative pigment percentages imply a seasonal shift in the phytoplankton community, and are consistent with field measurements (Fig. 2). Blooms of larger-sized diatoms typically occur during winter-spring and in the plume region (O'Reilly \& Zetlin, 1998), which results in higher percentages of pigments abundant in diatoms (e.g. Fuco) that can be estimated from satellite data (Fig. 8). As grazing pressure increases and the river discharge rates decrease from winter-spring to summer, the dominant diatom community during winter-spring is succeeded by mixed phytoplankton populations of diatoms, cryptophytes, dinoflagellates, haptophytes, and cyanobacteria during summer (Adolf et al., 2006; Marshall \& Cohn, 1983). The relative percentages of pigments found in other phytoplankton, such as Zea in cyanobacteria and Perid in peridinin-containing dinoflagellates, may increase from winter-spring to summer and from the inner shelf to outer shelf (Fig. 8). Although we only showed pigment distributions for TChl_a, Fuco, Perid, and Zea, distributions of other pigments, such as TChl $\_b$ and Allo, also demonstrated the seasonal and spatial variation of other phytoplankton groups (e.g. prasinophytes and cryptophytes).

\subsection{Time-series analysis of pigment concentrations}

Satellite ocean color time-series analysis of phytoplankton pigment distributions was conducted to demonstrate the spatial and temporal variations of phytoplankton taxa. In the region influenced by the riverine discharge (e.g. the Chesapeake Bay plume region), differences in phytoplankton pigments between the inner shelf and outer shelf were noticeable, while the seasonal variation was less apparent on the inner shelf than on the outer shelf due to shallow bathymetry conditions and proximity to the bay mouth on the inner shelf (Figs. 7 and 9, and Table 6). For example, the yearly mean [TChl_a] varied over 9-fold from $3.894 \mathrm{mg} \mathrm{m}^{-3}$ at the inner shelf station $\left(-75.88^{\circ} \mathrm{W}, 36.96^{\circ} \mathrm{N}\right)$ to $0.402 \mathrm{mg} \mathrm{m}^{-3}$ at the outer shelf station $\left(-74.83^{\circ} \mathrm{W}, 36.40^{\circ} \mathrm{N}\right)$ of the SMAB, while the seasonal mean [TChl_a] varied only by 1.52 -fold from 2.978 to $4.520 \mathrm{mg} \mathrm{m}^{-3}$ at the inner shelf station but by 2.35 -fold from 0.219 to $0.515 \mathrm{mg} \mathrm{m}^{-3}$ at the outer shelf station (Table 6). In the semi-enclosed GoM, the difference between the inner shelf and outer shelf was less apparent than that in the SMAB, but the seasonal variation was more noticeable (Figs. 7 and 10 , and Table 6$)$. For example, the yearly mean [TChl_a] varied less than 3-fold from $1.537 \mathrm{mg} \mathrm{m}^{-3}$ at the inner shelf station $\left(-70.56^{\circ} \mathrm{W}\right.$, $\left.43.031^{\circ} \mathrm{N}\right)$ to $0.600 \mathrm{mg} \mathrm{m}^{-3}$ at the outer shelf station $\left(-69.8614^{\circ} \mathrm{W}\right.$, $42.8614^{\circ} \mathrm{N}$ ) in the GoM, while the seasonal mean [TChl_a] varied 3.23-fold from 0.857 to $2.774 \mathrm{mg} \mathrm{m}^{-3}$ at the inner shelf station and 1.91 -fold from 0.377 to $0.754 \mathrm{mg} \mathrm{m}^{-3}$ at the outer shelf station (Table 6). Except for Zea, the spatial and seasonal variations of accessory pigments were somewhat similar to that for TChl_a, 


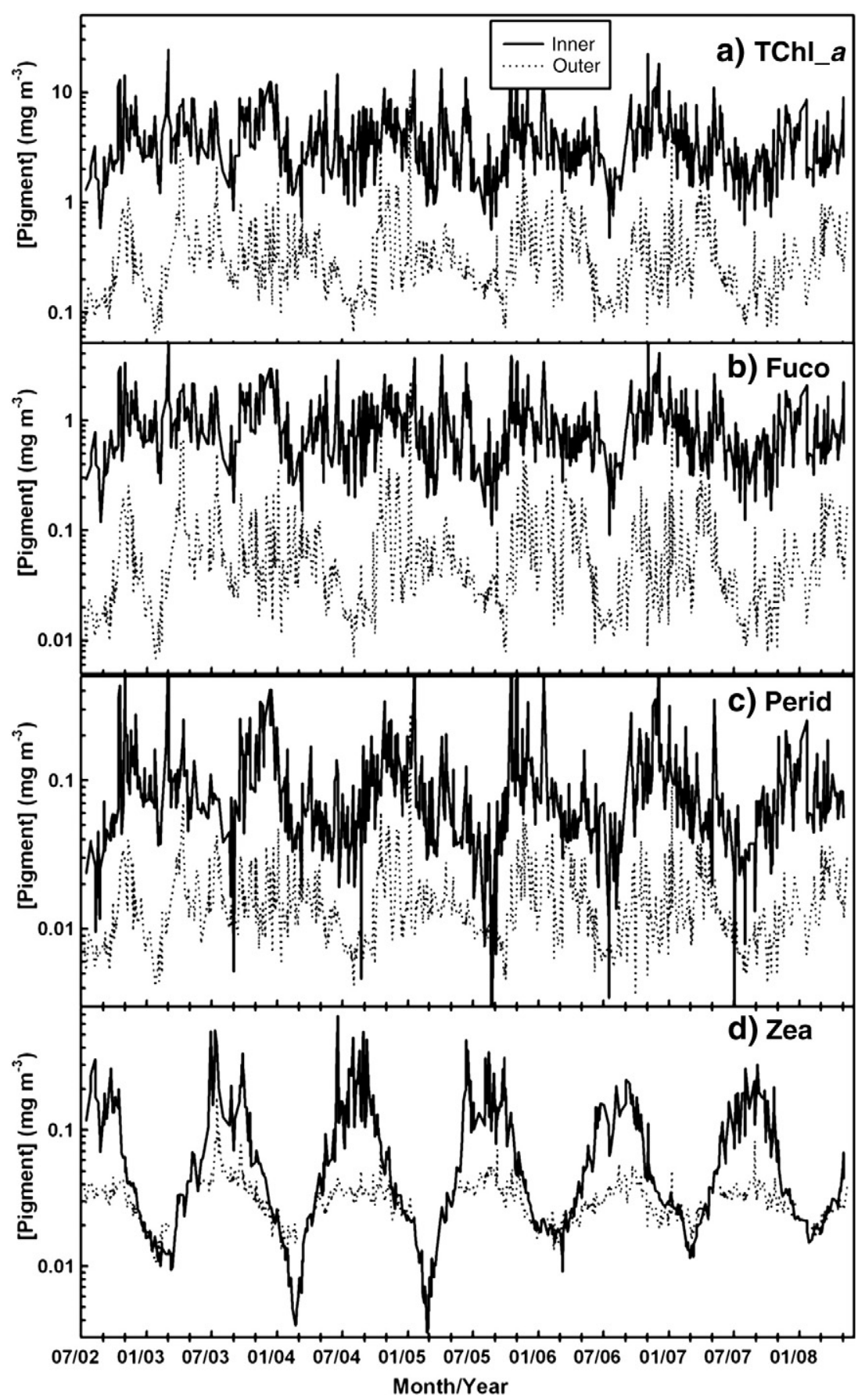

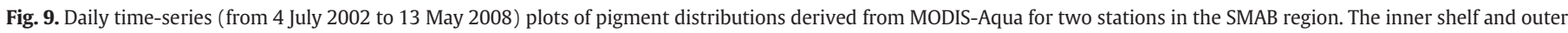

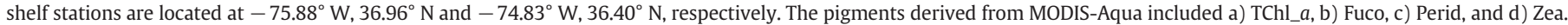

indicating the occurrence of mixed phytoplankton populations (Figs. 7, 9, and 10 and Table 6). Zea was subject to strong seasonal variability rather than spatial differences possibly due to the capability of cyanobacteria to fix nitrogen and the relatively rich supply of phosphonates in this region (Adolf et al., 2006; Dyhrman et al., 2006) (Figs. 7, 9, 10 and Table 6). The performance of satellitederived phytoplankton pigments was evaluated with available field measurements from the Gulf of Maine (source from University of New Hampshire Coastal Ocean Observing Center; website http://www. cooa.unh.edu/data/boats/bottle/). The satellite pigment products show generally good agreement with the available field measurements in the GoM (Fig. 10). For example, the MAPD and RMSE for [TChl_a] at the inner shelf station (WB2) were $57.4 \%$ and 0.237
$(N=5)$ for MODIS-Aqua within \pm 8 h satellite overpass time window, and $61.3 \%$ and $0.282(N=15)$ within $\pm 32 \mathrm{~h}$ satellite overpass time window. The MAPD and RMSE for [TChl_a] at the outer shelf station of the GoM (WB7) were $47.0 \%$ and $0.238(N=8)$ for MODIS-Aqua within \pm 3 or \pm 8 h satellite overpass time window, and $39.8 \%$ and 0.224 $(N=22)$ within \pm 32 h satellite overpass time window.

\section{Application and discussion}

\subsection{Algorithm development}

Bio-optical theory states that $R_{\mathrm{rs}}$ is related to backscattering and absorption from the contribution of pure water, phytoplankton, 
Table 6

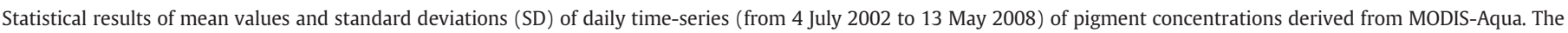

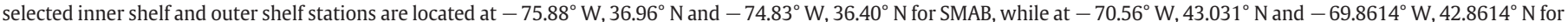
GoM, respectively. The defined seasons are spring (March-May), summer (June-August), fall (September-November), and winter (December-February).

\begin{tabular}{|c|c|c|c|c|c|c|c|c|c|c|}
\hline \multirow[t]{2}{*}{ Region } & \multirow[t]{2}{*}{ Season } & \multirow[t]{2}{*}{ Parameter } & \multicolumn{4}{|c|}{ Inner shelf station } & \multicolumn{4}{|c|}{ Outer shelf station } \\
\hline & & & TChl_a & Fuco & Perid & Zea & TChl_a & Fuco & Perid & Zea \\
\hline \multirow[t]{10}{*}{ SMAB } & \multirow[t]{2}{*}{ Spring } & Mean & 3.557 & 0.862 & 0.076 & 0.033 & 0.515 & 0.103 & 0.019 & 0.026 \\
\hline & & SD & 2.654 & 0.623 & 0.088 & 0.019 & 0.360 & 0.088 & 0.009 & 0.005 \\
\hline & \multirow[t]{2}{*}{ Summer } & Mean & 2.978 & 0.717 & 0.047 & 0.181 & 0.219 & 0.036 & 0.011 & 0.041 \\
\hline & & SD & 2.466 & 0.610 & 0.031 & 0.118 & 0.207 & 0.049 & 0.006 & 0.015 \\
\hline & \multirow[t]{2}{*}{ Fall } & Mean & 4.520 & 1.101 & 0.123 & 0.113 & 0.403 & 0.079 & 0.017 & 0.036 \\
\hline & & SD & 3.279 & 0.777 & 0.104 & 0.072 & 0.389 & 0.095 & 0.011 & 0.010 \\
\hline & \multirow[t]{2}{*}{ Winter } & Mean & 4.135 & 1.010 & 0.112 & 0.020 & 0.447 & 0.090 & 0.018 & 0.021 \\
\hline & & SD & 2.717 & 0.644 & 0.092 & 0.008 & 0.856 & 0.210 & 0.025 & 0.005 \\
\hline & \multirow[t]{2}{*}{ All } & Mean & 3.894 & 0.946 & 0.094 & 0.080 & 0.402 & 0.078 & 0.016 & 0.032 \\
\hline & & SD & 2.892 & 0.689 & 0.092 & 0.088 & 0.500 & 0.122 & 0.014 & 0.013 \\
\hline \multirow[t]{10}{*}{ GoM } & \multirow[t]{2}{*}{ Spring } & Mean & 2.774 & 0.651 & 0.041 & 0.005 & 0.719 & 0.154 & 0.020 & 0.006 \\
\hline & & SD & 4.296 & 1.018 & 0.078 & 0.008 & 1.087 & 0.268 & 0.011 & 0.006 \\
\hline & \multirow[t]{2}{*}{ Summer } & Mean & 0.957 & 0.210 & 0.020 & 0.037 & 0.440 & 0.084 & 0.016 & 0.033 \\
\hline & & SD & 0.473 & 0.118 & 0.012 & 0.009 & 0.206 & 0.049 & 0.006 & 0.009 \\
\hline & \multirow[t]{2}{*}{ Fall } & Mean & 1.596 & 0.372 & 0.033 & 0.029 & 0.754 & 0.163 & 0.026 & 0.027 \\
\hline & & SD & 1.322 & 0.331 & 0.028 & 0.011 & 0.939 & 0.230 & 0.027 & 0.008 \\
\hline & \multirow[t]{2}{*}{ Winter } & Mean & 0.857 & 0.187 & 0.030 & 0.003 & 0.377 & 0.073 & 0.016 & 0.004 \\
\hline & & SD & 0.464 & 0.120 & 0.013 & 0.004 & 0.582 & 0.146 & 0.016 & 0.004 \\
\hline & \multirow[t]{2}{*}{ All } & Mean & 1.537 & 0.353 & 0.033 & 0.013 & 0.600 & 0.125 & 0.020 & 0.019 \\
\hline & & SD & 2.431 & 0.580 & 0.043 & 0.015 & 0.823 & 0.203 & 0.018 & 0.014 \\
\hline
\end{tabular}

detritus, and CDOM (Kirk, 1994; Mobley, 1994). The more robust empirical algorithms for phytoplankton pigments may occur in an environment where phytoplankton provide the greatest contribution to $R_{\mathrm{rs}}$ and where phytoplankton community composition is less variable. This is not the case for our study region. In the SMAB region, for example, CDOM absorption can be significantly greater than phytoplankton absorption at shorter wavelengths, while resuspended matter can also be significant, particularly within the inner shelf region (Mannino et al., 2008; Pan et al., 2008). Semi-analytic (SA) models, such as GSM01 (Garver \& Siegel, 1997; Maritorena et al., 2002), may provide a possible solution to derive phytoplankton absorption, from which pigments may be derived. However, SA models typically assume constant specific ratios relative to a reference wavelength for constituent absorption and backscattering (Maritorena et al., 2002). Such an assumption may become inappropriate in optically complex coastal waters, which in turn augments the difficulty in deriving phytoplankton absorption from satellite ocean color sensors. Even if the derivations of phytoplankton absorption spectra are reasonable, the inversion to pigment concentrations may still be difficult. Pigments categorized within the same group, such as Perid and Fuco from the photosynthetic carotenoid pigments (PSC), have similar absorption spectra (Bricaud et al., 2007), which complicates our capability to distinguish the less abundant pigment (e.g. Perid in this region) from a more abundant pigment (e.g. Fuco in this region). Additional information of phytoplankton absorption spectra beyond what can be retrieved with the current limited set of satellite bands from SeaWiFS and MODIS-Aqua ( $N=6$ to 7 visible bands) is required to separate pigments with similar absorption spectra. Although our empirical algorithms can be improved further with larger datasets, at present these algorithms provide a possible solution to improving estimates of other variables such as primary production and phytoplankton biodiversity. An obvious concern for our empirical algorithms is that pigment concentrations are derived from a limited set of $R_{\mathrm{rs}}$ bands $(N=2$ or 3$)$, which are partly dependent upon each other. Such a problem can be overcome by future satellite sensors with a much larger set of bands, e.g. by adding more bands between 460 and $580 \mathrm{~nm}$ where absorption from Chl_a is weak but strong for accessory pigments.

\subsection{Phytoplankton community composition and algal population monitoring}

Knowledge of pigment concentration and composition has proven suitable to the study of phytoplankton community composition through chemotaxonomic analysis such as the CHEMTAX program (Mackey et al., 1996) and cell size estimations (Vidussi et al., 2001). As shown in Figs. 7 and 8, the distribution of biomarker pigments (e.g. Zea) typically coincided with the seasonal and spatial variation of the phytoplankton community. Marine phytoplankton biodiversity is typically a unimodal function of biomass (Irigoien et al., 2004). A high level of biomass (as indicated by [TChl_a]) during winter-spring typically implies a low level of biodiversity dominated by diatoms. Therefore, although pigments other than TChl_a, such as Perid, may also be relatively abundant in spring (Figs. 7-10), diatoms and not dinoflagellates typically dominate during winter-spring. In other words, other phytoplankton taxa with lower densities are obscured by abundant populations of diatoms during winter-spring. Intermediate levels of phytoplankton biomass during summer typically imply a high level of biodiversity with a mixture of diatoms, dinoflagellates, golden-brown algae (cryptophytes and hyptophytes), cyanobacteria, etc. (Adolf et al., 2006; Irigoien et al., 2004; Marshall \& Cohn, 1983). High levels of accessory pigments under such conditions suggest nondiatom algal taxa. For example, high levels of [Zea] during summer (Figs. 9 and 10) suggest the presence of abundant cyanobacteria populations. Cyanobacteria blooms are stimulated by water temperatures greater than $20^{\circ} \mathrm{C}$ (Jeffrey et al., 1997; Reynolds \& Walsby, 1975). Under such conditions, nutrient upwelling of cold water from below the surface mixed-layer is typically restricted. The higher efficiency of nutrient utilization due to their small size $(<2 \mu \mathrm{m}$ and thus higher surface-to-volume ratio) and the capability to fix nitrogen in certain species of cyanobacteria, permits cyanobacteria to grow faster than other phytoplankton species in warmer, nutrient-poor waters (Sellner, 1997).

The direct relationship of phytoplankton pigments to phytoplankton cell counts, however, must be applied with caution, even for taxaunique pigments. The cellular pigment concentration for certain taxa may be significantly different at various locations, different seasons, and even different growth phases. For example, cellular pigment concentrations are typically higher for cultures grown under a low light environment than for cultures grown under high light environment, but vary because of the effects of species-dependent growth phases, pigment composition, and growth irradiance (Johnsen et al., 1994; Lewitus et al., 2005). Lower light conditions occur more frequently within the surface mixed-layer on the inner shelf than outer shelf and during winter-spring than during summer, due to 


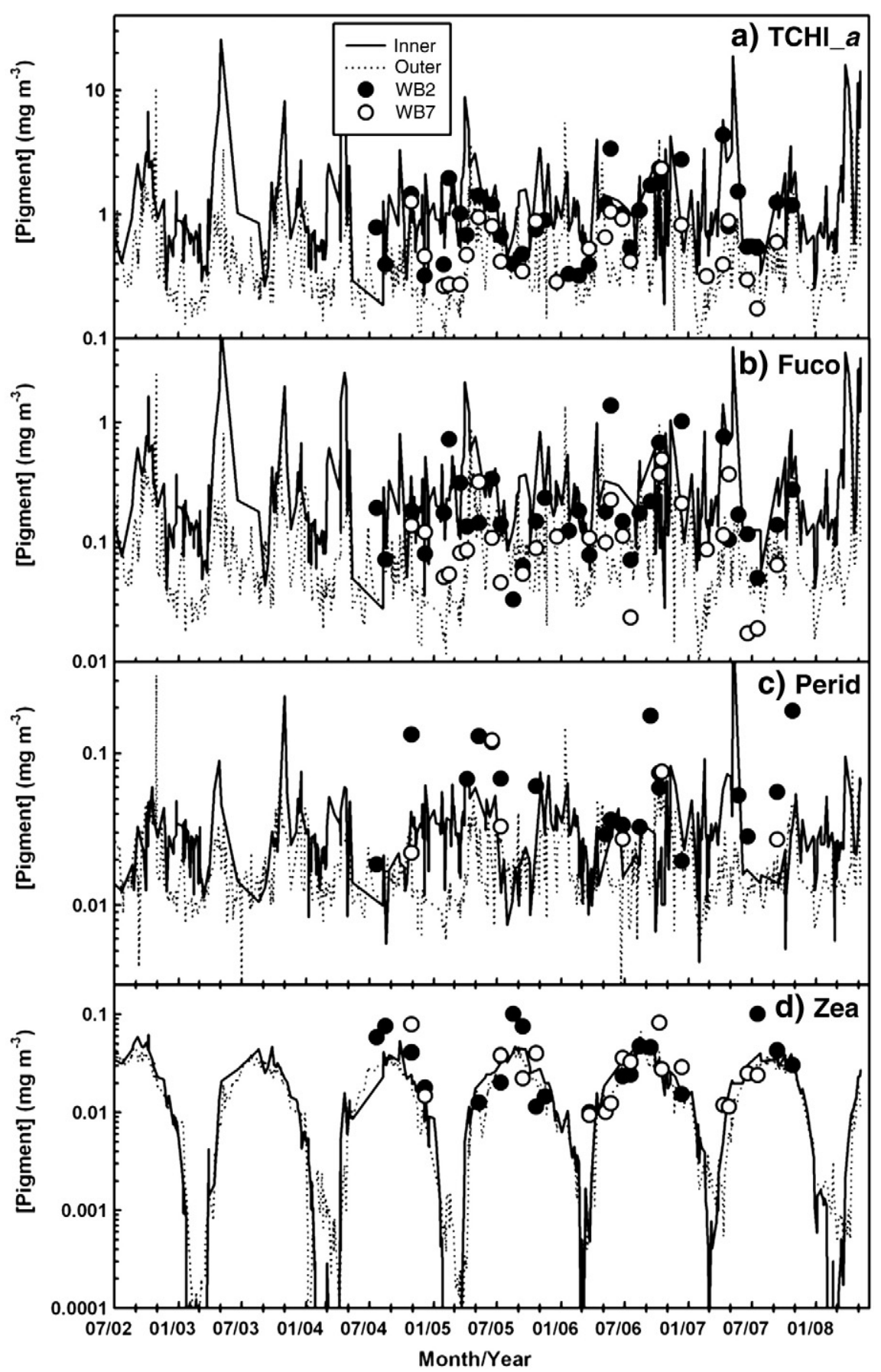

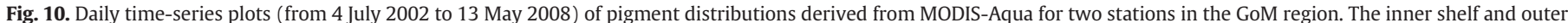

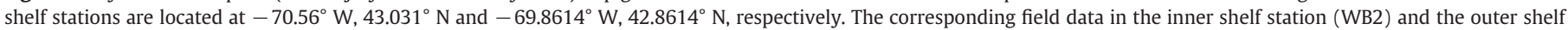

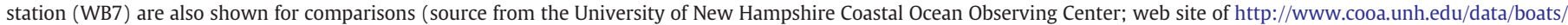
bottle/). The pigments derived from MODIS-Aqua included a) TChl_a, b) Fuco, c) Perid, and d) Zea.

light attenuation from absorbing constituents including CDOM, detritus, sediments and phytoplankton (Mannino et al., 2008; Pan et al., 2008). Therefore, it is reasonable to consider that the cellular pigment concentration is higher during winter-spring than during summer, and higher on the inner shelf than on the outer shelf. For example, cellular [Perid] during spring and fall (lower light environment) may be 2-5 times of that during summer (higher light environment) (Johnsen et al., 1994). That may explain partly why higher [Perid] may occur during spring (e.g. April) and fall (e.g. October) in the western GoM, but higher dinoflagellate cell counts are typically observed in early summer (e.g. May) (Anderson et al., 2005).
Many photosynthetic dinoflagellate species (e.g. Karenia brevis, $K$. mikimotoi, and Karlodinium micrum) contain Fuco, But-Fuco, and/or Hex-Fuco as accessory pigment rather than Perid (Hackett et al., 2004; Jeffrey et al., 1997). For example, gyroxanthin-diester, an accessory pigment that indicates fucoxanthin-containing dinoflagellates (e.g. Gymnodinium breve), was observed in the Delaware plume region during summer (BIOME4 cruise; unpublished data), and the upper range of this pigment of $0.05 \mathrm{mg} \mathrm{m}^{-3}$ suggests the presence of roughly $10^{5}$ cells per liter of fucoxanthin-containing dinoflagellates (Millie et al., 1997). Marshall et al. (2006) also showed that Gymnodinium spp. was one of the dominant dinoflagellates in the lower Chesapeake Bay in both 
spring and summer. Therefore, detailed analyses of phytoplankton community composition and remote sensing of algal populations should rely on the complete analyses of HPLC pigments (e.g. CHEMTAX program), cell counts, and in situ radiometric data, along with knowledge of phytoplankton physiology.

\section{Conclusions}

Our empirical algorithms demonstrated relatively successful satellite retrievals of phytoplankton pigments within a reasonable agreement (e.g. $\pm 35 \%$ of uncertainty), with better agreement for pigments abundant in diatoms. Significant improvements for our TChl_a algorithms were also found as compared to the operational OC4V4 and OC3M algorithms. The satellite images demonstrate that higher densities of diatoms (as indicated by TChl_ $a$ and Fuco concentrations) occur more prevalently on the inner shelf during winter-spring and fall when there is a sufficient supply of nutrients from riverine discharge. Although other accessory pigments (e.g. Perid) may be relatively high during these periods, the presence of peridinin-containing dinoflagellates may be obscured by the large populations of diatoms. The fraction of [Fuco] decreased during summer, while the fractions from other accessory pigments increased, indicating seasonal shifts in phytoplankton community composition. Higher densities of cyanobacteria (as indicated by [Zea]) may occur during summer, and more commonly in the southern area of our study region where warmer water temperatures are found. The direct link between phytoplankton pigments and cell counts is complicated due to differences in cellular pigment concentrations, light environment, growth stage, and species differences. Successful retrievals of phytoplankton pigments can be applied to improve our knowledge of phytoplankton biodiversity, algal bloom monitoring, and primary production.

\section{Acknowledgements}

This research was supported by an appointment to the NASA Postdoctoral Program at the Goddard Space Flight Center (GSFC), administered by Oak Ridge Associated Universities through a contract with NASA. The work was supported by the NASA Ocean Biology and Biogeochemistry Program, Interdisciplinary Science, Biodiversity, New Investigator Program, Carbon Cycle Science and Earth Observing System programs. We thank $\mathrm{Ru}$ Morrison for the invitation to participate cruises in the Gulf of Maine and Mike Twardowski for planning the New York Bight cruises. We are also grateful to Dr. Tim Moore and colleagues at the University of New Hampshire Coastal Ocean Observing Center for providing their HPLC data for the Gulf of Maine. We thank the captains and crews of R/V Cape Henlopen, Hugh R. Sharp, Gulf Challenger, Connecticut, and Fay Slover. We are grateful to J. Morrow, J. Brown, D. D'Alimonte, and J.-N. Druon for deploying the profiling radiometer, and to L. Van Heukelem and C. Thomas for analyzing HPLC pigments, and the Ocean Biology Processing Group (OBPG) at GSFC for satellite data processing and distribution. We thank Peter Minnett (Associate Editor), and three anonymous reviewers for their thorough, thoughtful jobs and constructive comments.

\section{References}

Acker, J. G., Harding, L. W., Leptoukh, G., Zhu, T., \& Shen, S. (2005). Remotely-sensed chl a at the Chesapeake Bay mouth is correlated with annual freshwater flow to the Chesapeake Bay. Geophysical Research Letters, 32, L05061. doi:10.1029/2004GL 021852

Adolf, J. E., Yeager, C. L., Miller, W. D., Mallonee, M. E., \& Harding, L. W. (2006). Environmental forcing of phytoplankton floral composition, biomass, and primary productivity in Chesapeake Bay, USA. Estuarine Coastal and Shelf Science, 67. 108-122. doi:10.1016/j.ecss.2005.11.030.

Anderson, D. M., Keafer, B. A., McGillicuddy, D. J., Mickelson, M. J., Keay, K. E., Libby, P. S. et al. (2005). The ecology and oceanography of toxic Alexandrium fundyense blooms in the Gulf of Maine. Deep-Sea Research II, 52, 19-21.

Antoine, D., d'Ortenzio, F., Hooker, S. B., Becu, G., Gentili, B., Tailliez, D., et al. (2008). Assessment of uncertainty in the ocean reflectance determined by three satellite ocean color sensors (MERIS, SeaWiFS and MODIS-A) at an outer shelf site in the Mediterranean Sea (BOUSSOLE project). Journal of Geophysical Research, 113, C07013. doi:10.1029/2007JC004472.

Bailey, S. W., \& Werdell, P. J. (2006). A multi-sensor approach for the on-orbit validation of ocean color satellite data products. Remote Sensing of Environment, 102, 12-23.

Behrenfeld, M. J., Boss, E., Siegel, D. A., \& Shea, D. M. (2005). Carbon-based ocean productivity and phytoplankton physiology from space. Global Biogeochemical Cycles, 19, GB1006. doi:10.1029/2004GB002299.

Behrenfeld, M. J., \& Falkowski, P. G. (1997). Photosynthetic rates derived from satellitebased chlorophyll concentration. Limnology and Oceanography, 42(1), 1-20.

Bricaud, A., Mejia, C., Blondeau-Patissier, D., Claustre, H., Crepon, M., \& Thiria, S. (2007). Retrieval of pigment concentrations and size structure of algal populations from their absorption spectra using multilayered perceptrons. Applied Optics, 46, 1251-1260.

Carder, K. L., Hawes, S. K., Baker, K. A., Smith, R. C., Steward, R. G., \& Mitchell, B. G. (1991). Reflectance model for quantifying chlorophyll a in the presence of productivity degradation products. Journal of Geophysical Research, 96, 20599-20611.

Dyhrman, S. T., Chappell, P. D., Haley, S. T., Moffett, J. W., Orchard, E. D., Waterbury, J. B., et al. (2006). Phosphonate utilization by the globally important marine diazotroph Trichodesmium. Nature, 439, 68-71.

Ecology and Oceanography of Harmful Algal Blooms (ECOHAB) workshop report. (1994). Snow Mountain Ranch Conference Center, Colorado, 23-28 August 1994. www.whoi.edu/science/B/redtide/nationplan/ECOHAB/ECOHABhtml.

Garver, S. A., \& Siegel, D. A. (1997). Inherent optical property inversion of ocean color spectra and its biogeochemical interpretation: 1 . Time series from the Sargasso Sea. Journal of Geophysical Research, 102(C8), 18607-18625.

Hackett, J. D., Anderson, D. M., Erdner, D. L. \& Bhattacharya, D. (2004). Dinoflagellates: A remarkable evolutionary experiment. American Journal of Botany, 91(10), 1523-1534.

Harding, L. W., Magnuson, A., \& Mallonee, M. E. (2005). SeaWiFS retrievals of chlorophyll in Chesapeake Bay and the mid-Atlantic bight. Estuarine Coastal and Shelf Science, 62, 75-94.

Hooker, S. B., Maritorena, S., Zibordi, G., \& McLean, S. (2001). Results of the second SeaWiFS data analysis round-robin, March 2000 (DARR-00). In S. B. Hooker, \& E. R. Firestone (Eds.), NASATech. Memo. 2001-206892, Vol. 15,Greenbelt, Maryland: NASA Goddard Space Flight Center 71 pp.

Hooker, S. B., Van Heukelem, L., Thomas, C. S., Claustre, H., Ras, J., Barlow, R., et al. (2005). The second SeaWiFS HPLC analysis round robin experiment (SeaHARRE-2). NASA TM/2005-212785, NASA Goddard Space Flight Center, Greenbelt, Maryland.

International Ocean-Colour Coordinating Group (IOCCG). (1999). Status and plans for satellite ocean-colour missions: Considerations for complementary missions. In J. Yoder (Ed.), Reports of the International Ocean-Color Coordinating Group, no. 2 Dartmouth, Nova Scotia.

International Ocean-Colour Coordinating Group (IOCCG). (2000). Remote sensing of ocean color in coastal, and optically-complex waters. In S. Sathyendranath (Ed.), Reports of the International Ocean-Color Coordinating Group, no. 3 Dartmouth, Nova Scotia.

Irigoien, X., Huisman, J., \& Harris, R. P. (2004). Global biodiversity patterns of marine phytoplankton and zooplankton. Nature, 429, 863-867.

Jeffrey, S. W., Mantoura, R. F. C., \& Wright, S. W. (1997). Phytoplankton pigments in oceanography. Paris: UNESCO Publishing.

Johnsen, G., Nelson, N. B., Jovine, R. V. M., \& Prezelin, B. B. (1994). Chromoprotein- and pigment-dependent modeling of spectral light absorption in two dinoflagellates, Prorocentrum minimum and Heterocapsa pygmaea. Marine Ecology Progress Series, $114,245-258$

Kirk, J. T. O. (1994). Light and phytosynthesis in aquatic ecosystems, 2nd ed. New York: Cambridge University Press.

Lee, Z. P., \& Carder, K. L. (2004). Absorption spectrum of phytoplankton pigments derived from hyperspectral remote-sensing reflectance. Remote Sensing of Environment, 89, $361-368$.

Lewitus, A. J., White, D. L., Tymowski, R. G., Geesey, M. E., Hymel, S. N., \& Noble, P. A. (2005). Adapting the CHEMTAX method for assessing phytoplankton taxonomic composition in southeastern U.S. estuaries. Estuaries, 28(1), 160-172.

Mackey, M. D., Mackey, D. J., Higgins, H. W., \& Wright, S. W. (1996). CHEMTAX-A program for estimating class abundances from chemical markers: Application to HPLC measurements of phytoplankton. Marine Ecology Progress Series, 144, $265-283$.

Magnuson, A., Harding, L. W., Mallonee, M. E., \& Adolf, J. E. (2004). Bio-optical model for Chesapeake Bay and Middle Atlantic Bight. Estuarine Coastal and Shelf Science, 61, 403-424.

Mannino, A., Russ, M. E., \& Hooker, S. B. (2008). Algorithm development and validation for satellite-derived distributions of DOC and CDOM in the U.S. Middle Atlantic Bight. Journal of Geophysical Research, 113, C07051. doi:10.1029/2007JC004493.

Maritorena, S., Siegel, D. A., \& Peterson, A. R. (2002). Optimization of a semianalytical ocean color model for global-scale applications. Applied Optics, 41, 2705-2714.

Marra, J., Ho, C., \& Trees, C. C. (2003). An alternative algorithm for the calculation of primary productivity from remote sensing data. LDEO Technical Report \# LDEO2003-1, Lamont-Doherty Earth Observatory of Columbia University, New York

Marra, J., Trees, C. C., Bidigare, R. R., \& Barber, R. T. (2000). Pigment absorption and quantum yields in the Arabian Sea. Deep-Sea Research II, 47, 1279-1299.

Marra, J., Trees, C. C., \& O'Reilly, J. E. (2007). Phytoplankton pigment absorption: A strong predictor of primary productivity in the surface ocean. Deep-Sea Research I, $54,155-163$

Marshall, H. G., \& Cohn, M. S. (1983). Distribution and composition of phytoplankton in northeastern coastal waters of the United States. Estuarine Coastal and Shelf Science, $17,119-131$

Marshall, H. G., Lacouture, R. V., Buchanan, C., \& Johnson, J. M. (2006). Phytoplankton assemblages associated with water quality and salinity regions in Chesapeake Bay, USA. Estuarine Coastal and Shelf Science, 69, 10-18. 
McClain, C. R. (2009). A decade of satellite ocean color observations. Annual Review of Marine Science, 1, 19-42. doi:10.1146/annurev.marine.010908.163650.

Millie, D. F., Schofield, O. M., Kirkpatrick, G. J., Johnsen, G., Tester, P. A., \& Vineyard, B. T. (1997). Detection of harmful algal blooms using photopigments and absorption signatures: A case study of the Florida red tide dinoflagellate, Gymnodinium breve. Limnology and Oceanography, 42(5, part 2), 1240-1251.

Mobley, C. (1994). Light and water: Radiative transfer in natural waters. San Diego: Academic Press.

Mueller, J. L., \& Austin, R. W. (1995). Ocean optics protocols for SeaWiFS validation, revision 1. In S. B. Hooker, E. R. Firestone, \& J. G. Acker (Eds.), NASA tech. memo. 104566, Vol. 25,Greenbelt, Maryland: NASA Goddard Space Flight Center 66 pp.

O'Reilly, J. E., Maritorena, S., Mitchell, B. G., Siegel, D. A., Carder, K. L., Garver, S. A., et al. (1998). Ocean color algorithms for SeaWiFS. Journal of Geophysical Research, 103, 24937-24953.

O'Reilly, J. E., Maritorena, S., Siegel, D., O'Brien, M. C., Toole, D., Mitchell, B. G., et al. (2000). SeaWiFS postlaunch calibration and validation analyses, part 3. In S. B. Hooker, \& E. R. Firestone (Eds.), SeaWiFS post-launch technical report series. NASA technical memorandum 2000-206892, Volume 11,. Greenbelt, Maryland: NASA Goddard Space Flight Center.

O'Reilly, J. E., \& Zetlin, C. (1998). Seasonal, horizontal, and vertical distribution of phytoplankton chlorophyll a in the northeast U.S. continental shelf ecosystem. NOAA technical report NMFS 139, U.S. Department of Commerce, Seattle, Washington.

Pan, X., Mannino, A., Russ, M. E., \& Hooker, S. B. (2008). Remote sensing of the absorption coefficients and chlorophyll a concentration in the United States southern Middle Atlantic Bight from SeaWiFS and MODIS-Aqua. Journal of Geophysical Research, 113, C11022. doi:10.1029/2008JC004852.

Pope, R. M., \& Fry, E. S. (1997). Absorption spectrum (380-700 nm) of pure water. II. Integrating cavity measurements. Applied Optics, 36, 8710-8723. doi:10.1364/ A0.36.008710.
Reynolds, C. S., \& Walsby, A. E. (1975). Water blooms. Biological Reviews, 50, 437-481. Sathyendranath, S., Hoge, F. E., Platt, T., \& Swift, R. N. (1994). Detection of phytoplankton pigments from ocean color: Improved algorithms. Applied Optics, 33, $1081-1089$.

Sathyendranath, S., Platt, T., Stuart, V., Irwin, B. D., Veldhuis, M. J. W., Kraay, G. W., et al. (1996). Some bio-optical characteristics of phytoplankton in the NW Indian Ocean. Marine Ecology Progress Series, 32, 299-311.

Sellner, K. G. (1997). Physiology, ecology, and toxic properties of marine cyanobacteria blooms. Limnology and Oceanography, 42(5, part 2), 1089-1104.

Smyth, T. J., Groom, S. B., Cummings, D. G., \& Llewellyn, C. A. (2002). Comparison of SeaWiFS bio-optical chlorophyll- $a$ algorithms within the OMEXII programme. International Journal of Remote Sensing, 23(11), 2321-2326.

Sosik, H. M., \& Mitchell, B. G. (1995). Light absorption by phytoplankton, photosynthetic pigments and detritus in the California Current System. Deep-Sea Research I, 42(10), 1717-1748.

Uitz, J., Claustre, H., Griffiths, F. B., Ras, J., Garcia, N., \& Sandroni, V. (2009). A phytoplankton class-specific primary production model applied to the Kerguelen Islands region (Southern Ocean). Deep-Sea Research I, 56(4), 541-560. doi: 10.1016/j.dsr.2008.11.006.

Van Heukelem, L., \& Thomas, C. S. (2001). Computer-assisted high-performance liquid chromatography method development with applications to the isolation and analysis of phytoplankton pigments. Journal of Chromatography A, 910, 31-49.

Vidussi, F., Claustre, H., Manca, B. B., Luchetta, A., \& Marty, J. C. (2001). Phytoplankton pigment distribution in relation to upper thermocline circulation in the eastern Mediterranean Sea during winter. Journal of Geophysical Research, 106(C9), 19939-19956.

Werdell, P. J., Bailey, S. W., Franz, B. A., Harding, L. W., Feldman, G. C., \& McClain, C. R. (2009). Regional and seasonal variability of chlorophyll-a in Chesapeake Bay as observed by SeaWiFS and MODIS-Aqua. Remote Sensing of Environment, 113 1319-1330. doi:10.1016/j.rse.2009.02.012. 